\title{
A Mennydörgés Istenének amerikanizálása: hogyan lesz a fiúuralkodóból Asgard jogos királya a Thor ban
}

\begin{abstract}
Absztrakt
A tanulmány Terence McSweeney Avengers Assemble! Critical Perspectives on the Marvel Cinematic Universe címú könyvének két szövegéből áll, amelyek könnyedén illeszkednek egymáshoz. A Thor ral (Kenneth Branagh, 2011) foglalkozó elsố részben a filmet az amerikai monomítoszokkal és az amerikai politikával, valamint az Egyesült Államokon kívüli amerikai beavatkozással veti össze a szerzô, látványos párhuzamokat vonva. A tanulmány második fele a Thor: Sötét világon (Thor: Dark World. Alan Foster, 2014) keresztül a Marvel-filmek problémás nóábrázolását mutatja be, kiemelt helyen kezelve Thor szerelmét, Jane Fostert.
\end{abstract}

\section{Szerzô}

Terence McSweeney a southamptoni Solent Egyetemen filmtudományt tanít, emellett az Oxfordi Egyetemen és a londoni Queen Mary Egyetemen is kapott már kutatói pozíciót. Egyik fố területe a kortárs amerikai mozi, ennek keretében született meg a szuperhősfilmekröl szóló könyve, az Avengers Assemble! Critical Perspectives on the Marvel Cinematic Universe. McSweeney széleskörü érdeklődését jelzi, hogy a kortárs amerikai film csak egy a számos téma közül, amellyel foglalkozik, írt már könyvet Tarkovszkijról, a 9/11-et övezô traumakultúráról, de érdeklődési körébe tartozik a dél-koreai és az orosz film vagy a zombifilm témaköre is.

https://doi.org/10.31176/apertura.2019.15.1.4 


\section{Terence McSweeney}

\section{A Mennydörgés Istenének amerikanizálása: hogyan lesz a fiúuralkodóból Asgard jogos királya a Thor ban}

Az ember istenek alkotója, és mindig is az volt. Ez a legkomolyabb és legjelentôsebb tevékenysége, amióta csak létezik ezen a világon. ${ }^{[1]}$

John Burroughs (1913: 184)

Az elmúlt években számos írás, például Don LoCicero Szuperhösök és istenek: Összehasonlitó tanulmány Babilontól Batmanig (2007), Grant Morrison Szuperistenek: világunk a szuperhös korában (2012) és Ben Saunders „Viselnek-e csuklyát az istenek”? A spiritualitás, a fantasy és a szuperhösök (2012) címú könyve meggyőzően állította, hogy a szuperhôsök nemcsak támogatják az uralkodó társadalmi értékeket és viselkedést, hanem istenszerú szerepet töltenek be az azokat elóállító kultúrákban. Noha a Marvel-moziverzum (Marvel Cinematic Universe - MCU) diegetikus világában is gyakran efféle figuráknak tekintik a szuperhôsöket, Thor, a mennydörgés asgardi istene s e fejezet egyik tárgya, az egyedüli az elsô Bosszúállók közt, aki a szó szoros értelmében is isten. Martin Arnold Thor: a mítosztól a Marvelig (2011a) címú múve felvázolja Thor gazdag történetét, kezdve az ôsi norvég és skandináv szövegekben fellehetô eredetétôl - például a verses Eddában és a prózai Eddában (13. század) ahol ó volt a levegő és termékenység istene, valamint „az emberiség védelmezôje" - a tizennyolcadik és tizenkilencedik századon keresztül, amikor számos romantikus költő és nacionalista mozgalom inspirációjává vált, egészen a huszadik századig, amelynek első felében a náci Németország nemzeti istenének tették meg (2011a: 135). Jon Favreau Vasembere (Iron Man, 2008) kockázatos vállalkozás volt az újonnan alapított Marvel Studios számára, ám Tony Stark karaktere és fémalteregója mégiscsak az Egyesült Államok huszonegyedik századi kvázi realisztikus környezetéhez illeszkedik. Thor karaktere, tekintve annak skandináv mitológiai gyökereit és azt a tényt, hogy természetfeletti hatalommal bír és valóban isten, másféle kihívások elé állította az alkotókat, amikor a Marvel történetében elôször a karaktert mozivászonra adaptálták.

Az asgardiak égi státusza kissé homályos marad az egész MCU-ban. A Bosszúállókban (The Avengers. Joss Whedon, 2012) Coulson ügynök és Nick Fury istennek hívja ôket, csakúgy mint Loki, Thor bajkeveró és rosszindulatú fivére. A Thorban (Thor. Kenneth Branagh, 2011) Fandral, a Három Harcos egyike, egy ettôl kissé eltérô lehetôséget sugall, amikor Thorhoz szólva így fogalmaz: „a halandók istenként tisztelnek”. ${ }^{[2]}$ A Thor: Sötét világban (Thor: The Dark World. Alan Foster, 2014) a különös jelentôségú New York-i csata után a megszégyenült Loki leláncolva tér 
vissza apja, Odin elé, ahol a következó magyarázatot adja a tetteire: „Midgardba mentem, hogy uralkodjam a Föld lakói felett, mint isten. Úgy, mint te.” De Odin nem ért egyet, mondván: „Nem vagyunk istenek! Megszületünk és meghalunk, mint az emberek.” Az isteni létnek ez a kétértelmúsége gyakran humor forrásává válik, például amikor a pityókás Erik Selvig (Stellan Skarsgård) azzal fejezi be a Thor társaságában eltöltött részeges mulatságot, hogy azt mondja neki: „Még mindig nem hiszem, hogy a mennydörgés istene vagy, de bár az lennél!”, vagy amikor Amerika kapitány nem ismeri el Thor istenségét a Bosszúállókban, a következô szavakat intézve a Fekete Özvegyhez: „Csak egy Isten van, hölgyem, és lefogadom, hogy nem ilyen ruhát hord.”[3]

A Vasemberhez hasonlóan a Marvel Thorját is a hidegháború idején alkották meg, megjelenése Tony Starkét is megelôzi a Journey into Mystery 83. számában (1962. augusztus). De Thor abban is fémpáncélos kollégájához hasonlít, hogy asgardi másvilági státusza ellenére is gyakran kapcsolták e korszak amerikai értékeihez és külpolitikájához. Martin Arnold szerint a karaktert „úgy alakították, hogy egyszerre fejezze ki a férfiszexualitással kapcsolatos szorongást, és ezzel párhuzamosan az amerikai külpolitikával kapcsolatos félelmeket is" (201la, hátlap). A hidegháború idején a nevével fémjelzett képregényekben Thor számos valós konfliktusban vett részt, ahol politikai perspektívái határozottan amerikai nézôpontot tükröztek, és még Vietnamban is többször beavatkozott. 1965-ben a Journey into Mystery 117. számában Hu Sak kommunista parancsnokot ordítja le: „Ami a kommunizmust illeti - bár eltúnne végre a föld színérôl és az emberiség emlékezetéből”. ${ }^{[4]}$ Az MCU szintén az akciók bajnokaként ábrázolja Thort, acélos testú hôsként, amely típus Susan Jeffords szerint az Egyesült Államok önképének emblematikus megjelenítôje. Mint Jeffords az Acélos testek: hollywoodi férfiasság a Reagan-korban címú könyvében írja: „A fáradhatatlan, izmos és legyőzhetetlen férfias test ábrázolása lett a Reagan-korszakbeli képzetvilág tartóoszlopa; ez a megkeményedett férfialak nemcsak a Reagan-elnökség, hanem az ahhoz kötôdő ideológia és gazdaságpolitika emblémájává is vált” (1994: 25). Thort azonban, az új évezred termékeként, ennél árnyaltabban ábrázolják. A korszak sok egyéb maszkulin alakjához hasonlóan ô is az acélos test és a korábbinál érzékenyebb, új férfiasság archetípusát kombinálja, ami a kor diszkurzusaira általában is jellemző.

Thor istenségét bizonyára nehéz volt összeegyeztetni az MCU szélesebb narratívájával 2011-ben, a rendezô Kenneth Branagh-nek azonban sikerült azt a film szerves részévé tenni, ahelyett, hogy figyelmen kívül hagyta volna, mivel a film egyfolytában a tudomány és a fantázia, a mítosz és a valóság összefonódásával szembesít. A film, amely az Odint - Thor apját, Asgard királyát és a Mindenek Atyját - alakító Anthony Hopkins sztentori hangjával kezdôdik, már a legelsô pillanatban ezt tematizálja a hangi narrációval:

„Egykor az emberi faj elfogadta az egyszerú igazságot: hogy nincsen egyedül az univerzumban. Az emberek úgy tartották, van egy világ, amely az isteneik otthona, és vannak világok, amelyektől félniük kell. A hideg és a sötét birodalmából jöttek a Jégóriások, hogy a halandó világot jégkorszakba taszítsák. De az emberiség nem egyedül nézett szembe ezzel a vésszel. Seregeink visszaverték a Jégóriásokat saját világuk szívébe. 
Sok volt az áldozat. De végül a királyuk elesett, és erejük forrását elvették tôlük. Mikor a nagy háború véget ért, kivonultunk a másik világokból, és visszatértünk az Örök Birodalomba, Asgardba. Itt maradunk reménysugárként, mely átragyog a csillagok között. És noha az emberek számára mítoszokká és legendákká lettünk, mégis Asgard és harcosai hoztak békét az univerzumnak."

A nő, aki Thor szerelme lesz, az asztrofizikus (az eredeti képregényben még ápolónő) Jane Foster (Natalie Portman), Arthur C. Clarke nyomán azt sugallja, hogy ez a két terület összeegyeztethetô, mivel „a varázslat olyan tudomány, amit még nem értünk” (lásd Clarke 1973: 21, 1-es lj.). Thor azt mondja neki: „Az ôseid varázslatnak nevezték, te pedig tudománynak. Ahonnét én jövök, ez a kettố ugyanaz.” A film jelentôs energiát fektet abba, hogy a tudományos tanácsadók segítségével összemossa a kettôt: Sean Carroll, a kaliforniai Múszaki Intézet elméleti fizikusa és $A z$ örökkévalóságtól idefelé címú könyv (2010) szerzôje, illetve Kevin Hand, a NASA asztrobiológusa a hitelesség patinájával látják el a filmet az Einstein-Rosen-hidak, az aurora borealis említésével (lásd Kakalios 2010; Hill 2013). Még az elismert népszerú tudós, Neil Degrasse Tyson is a Twitterhez nyúlt, hogy közzétegye meditációját arról, hogy számításai alapján, ha Thor híres kalapácsa, a Mjölnir egy neutroncsillag anyagából készült, ahogy Odin állítja a Thorban (egész pontosan azt mondja, hogy egy „kihunyó csillagban kovácsolták”), akkor annyit nyomhat, mint egy 300 milliárd elefántból álló csorda" (2013). A filmnek sikerül összeegyeztetnie a hôsi fantasyt a tudományos fantasztikummal Asgard ábrázolásában is, amely technológiailag fejlett - a lakói képesek bolygók közötti utazásra, futurisztikus ûrsiklókkal rendelkeznek, ám továbbra is kardot és pajzsot használnak, középkori ruhát hordanak, és fennkölt stílusban beszélnek. Ezzel kapcsolatban Tony Stark késóbb a Bosszúállókban egy viccet is megereszt, mondván, hogy olyan, mint a „Shakespeare-összes”, s így ugratja Thort: „Jó anyád tudja, hogy ruháit viseled”? Branagh képes gazdag humorral aláásni a melodramatikus hangulatot, minek következtében a film $A$ galaxis ốrzối (Guardians of the Galaxy. James Gunn, 2014) és A Hangya (Ant-Man. Peyton Reed, 2015) bemutatásáig az MCU komikummal leginkább átitatott darabja volt. ${ }^{[5]}$ Az elbeszélés során, amellett, hogy számos látványos csatában vesz részt, a hatalmas Thort Jane Foster kétszer is elgázolja, Jane jópofa asszisztense, Darcy Lewis (Kat Dennings) pedig egy elektromos sokkolóval üti ki.

A Vasember iraki nyitása helyett Thor elbeszélése Asgardban kezdődik, Thor koronázásának fényes és ragyogó napján, amikor a Mennydörgés Istene öregedó apja helyett trónra emelkedik. Gyorsan kiderül, hogy Thor arrogáns és túlontúl is magabiztos, amit a film magamutogatásával és öntelt kacsingatásával érzékeltet. Asgard, amelynek Thor az elsôdleges képviselôje, tudatosan az Amerikai Egyesült Államok reprezentánsaként konstruálódik meg, Odin leírása pedig, miszerint Asgard „reménysugár, mely átragyog a csillagok között”, nagyon emlékeztet az utóbbi kétszáz év azon számos kinyilatkoztatására, amely Amerikának a világban betöltött önjelölt szerepére vonatkozik. Ronald Reagan és Richard Nixon a beiktatási beszédeikben pontosan ezt a fordulatot használták, de ennek egyik változata hallható Donald Trump azon saját megfogalmazásában is, miszerint az amerikai életforma „ragyogó példa... Ragyogunk mindenki számára, hogy 
követhessenek" (2017). Amint azt Edwin J. Feulner és Brian Tracey Az amerikai szellem: azon erények és értékek ünneplése, amelyek naggyá tesznek minket címû́ könyvükben írják, „történelmünk során mi [az Amerikai Egyesült Államok] mindig és mindenütt a remény jelzójeként szolgáltunk az elnyomott férfiak és nôk számára." (2012: 53)

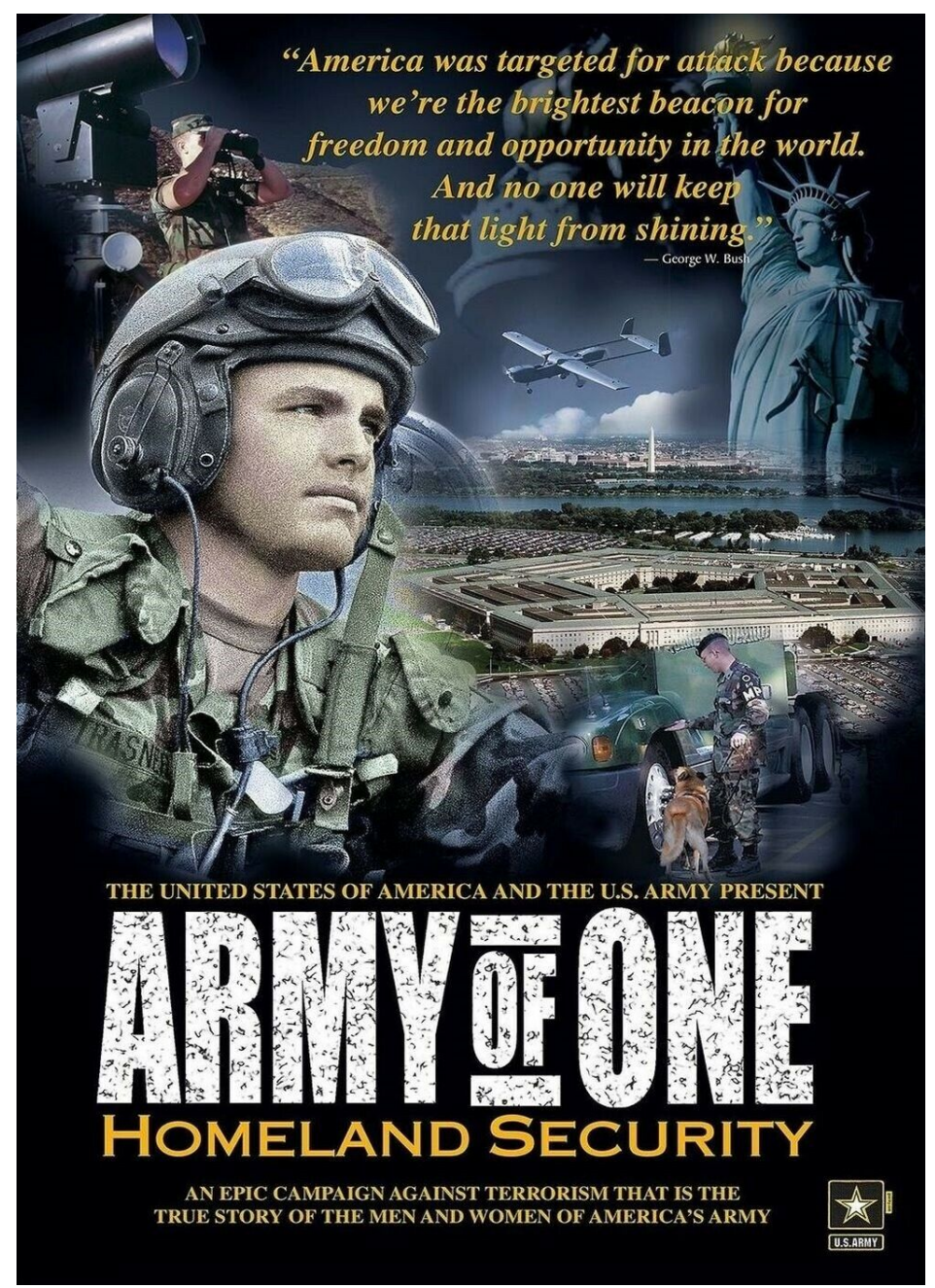

A hadsereg "Army of One" toborzókampánya során a terroristák által megtámadott USA-t a szabadság és lehetôségek ragyogó jelzốtüzeként jelenitették meg.

Asgard lakosai már nem az északi mitológia kék szemú szôkéi, hanem egy harmonikus többnemzetiségú társadalom, amelynek legfontosabb személyiségei közt még ázsiai (Tadanobu Asano mint Hogun, akirôl késôbb kiderül, hogy a vanirok közé tartozik) vagy afrikai származású (Idris Elba mint Heimdall) is akad. Vincent M. Gaine szerint „Ez az egyetemesség érzetét kelti, és megakadályozza, hogy Asgard az észak-európai mennyei birodalom egyik változataként jelenjen meg." (2016: 40) A Marvel 1962 óta vesz részt Thor amerikanizálásában, ami már a képregényekben is tetten érhetô, az MCU inkarnációjában pedig még erôsebbé vált. Ennek megnyilvánulása Asgard békés és utópikus többnemzetiségú közössége, de még inkább magának Thornak a jellemzése, aki megtestesíti, amit Hagley és Harrison az „amerikai harcos szellemiségnek" (2012) nevez, és kiáll az egyenlőség, szabadság és igazságosság Asgard által 
képviselt, de sokak által alapvetôen amerikainak tekintett értékei mellett. Ez az amerikanizáció 2011-re olyan mértékúvé vált, hogy Martin Arnold szerint elértük azt a pontot, amelyen túl „Thor recepciója végleg kiüresedett, mivel már senkit sem a norvég mítosz vagy a valaha istenként tisztelt Thor története érdekel, hanem csak az egzotikus skandináv külsôségek, amelyeket a populáris kultúra tömegtermelése végtelen ciklusokban dolgozhat fel újra és újra" (2011a: 65).

Miközben a békés asgardiak kiváltságos életüket élvezik, örök ellenségeik, a Jégóriások egy kisszámú csapata meglepó támadást indít a hosszú ideje bevehetetlennek gondolt Asgard ellen. Bár a kísérletet gyorsan elhárítja egy varázslatos fémlény, az úgynevezett Pusztító, az arrogáns és impulzív Thor vérszemet kap, és azonnali bosszút akar állni. Mint mondja, ha rajta múlna, „Bevonulnék Jöttunheimbe, ahogyan te [Odin] régen. Megleckéztetném óket. Megtörném óket, hogy többé ne merjék átlépni határainkat!" Thor nem érti tervezett akciójának lehetséges következményeit, s hogy hány életbe kerül mindkét oldalon, ha újrakezdik az ellenségeskedést, a bölcsebb Odin viszont óvatosságra és diplomáciára szólít fel a háború helyett, emlékeztetve, hogy a támadás „csak pár vakmerô” cselekedete volt, „akinek buknia kellett”. Odin évek óta törékeny békét tart fenn a két faj között, és kijelenti, hogy néhány támadó miatt, akik esetleg nem is képviselik egész népüket, nem kezdhetnek olyan konfliktust, amely tízezrek halálához vezethet. Az eseményeket és a vitákat, amelyben olyasféle mondatok hangzottak el, mint hogy „Ez harci cselekedet volt!”, és „Tudod, mit indítottál el?”, néhányan az ország szeptember 11. utáni politikai helyzetének burkolt kommentárjaként értelmezték. Többek között Anthony R. Mills is, aki Thor büszkeségének és hübriszének ábrázolásában a valódi világ reprezentációját látta, kijelentve: „Nehéz nem a kor politikai helyzetére gondolni, amikor Thor és Odin vitáját figyeljük azzal kapcsolatban, hogy mi a megfelelô válasz a Jégóriások fellépésére” (2013: 180). Thor érvelése, miszerint csak a Jégóriások elleni megelőzố csapás az, amivel „biztosíthatjuk határaink védelmét” már azelôtt véget vetve a háborúnak, mielôtt még igazán elkezdôdött volna, a Bush-doktrína szembetûnô megnyilvánulása. Ahogyan Peter Labuza A vég felé: az apokalipszis elképzelése az amerikai filmben (2014) címú könyvében állítja, a Thor „,erôteljesen rájátszik a George Bushsal való párhuzamra" (2011), s a film bemutatása után számos kritika jött ki olyan címekkel, mint $A$ nyár új höse: Thor-G. W. Bush (Singer 2011) vagy Bombasiker: Bush vs. Thor (Stewart 2011).

Mivel meg van gyôződve róla, hogy neki van igaza, testvére, Loki pedig (aki késôbb nagy bánatára megtudja, hogy valójában a Jégóriások leszármazottja, és csak örökbe fogadták) ügyesen manipulálja, Thor szembeszáll apja kívánságával, és egy támadó csapatot vezet Jöttunheimbe. Itt a Jégóriások királyával, Laufey-val találja szembe magát, aki azt vágja a fejéhez, hogy „A te apád egy gyilkos tolvaj” - pontosan ugyanazt a vádat, amelyet Ivan Vanko is felhoz Howard Stark ellen az elôzô évben bemutatott Vasember 2-ben (Iron Man 2. Jon Favreau, 2010). ${ }^{[6]}$ Ahogyan Vanko állításai az idôsebb Starkkal kapcsolatban hamisnak bizonyultak, úgy Laufey vádjai is megalapozatlanok, hiszen Odin a jóindulatú és bölcs uralkodó mintaképe, aki így okítja a fiait: „A bölcs király sosem akar háborút, de mindig készen áll rá”, míg a Jégóriások népe alig több, mint durva barbárok háborús karikatúrája. Amikor Laufey így szól Thorhoz: „Te vágysz a harcra. Epedsz érte. Csupán egy fiú vagy, aki férfinak akar látszani”, úgy túnik, mintha jobban ismerné az 
ingerlékeny herceget, mint az saját magát, s egyszersmind Chalmers Johnson emlékezetes jellemzését is felidézi, melyben George W. Busht „fiúuralkodónak” nevezte (2004: 283). Látva helyzetük súlyosságát és azt a tényt, hogy az ellenség reménytelenül túlerôben van, a Három Harcos és Lady Sif felszólítja Thort, hogy gondolja újra a félresikerült tervet, és egy pillanatra úgy tûnik, hogy Thor meg is fontolja ezt. Laufey azonban újra felszítja a harci kedvét, amikor megkérdôjelezi a férfiasságát: „Fuss csak haza, kicsi hercegnó!”, feltárva, hogy még egy isten számára is az a legnagyobb sértés, ha megkérdôjelezik a férfiasságát, és egy nốhöz hasonlítják. ${ }^{[7]}$

Kivételes harci bátorságuk ellenére egyértelmú, hogy az asgardiaiak kisebbségben vannak és gyengébbek, a vereség pillanatában azonban mitikus nyolclábú lován, Sleipniren lovagolva Odin tûnik fel. „Atyám! Együtt végzünk velük!” - szólítja Thor az apját, ami erôsen megidézi, hogyan gondolt sokak szerint George W. Bush az iraki háborúra. ${ }^{[8]}$ Odin azonban figyelmen kívül hagyja a fiát, és Laufey-hez fordul: „Ezek egy fiú cselekedetei, kezeld akképpen” - s ez a második eset néhány percen belül, hogy Thort fiúnak nevezik. Laufey azonban nem áll kötélnek, és a civilizációk összecsapása ${ }^{[9]}$ az asgardiaiak és a Jégóriások között újrakezdődik.

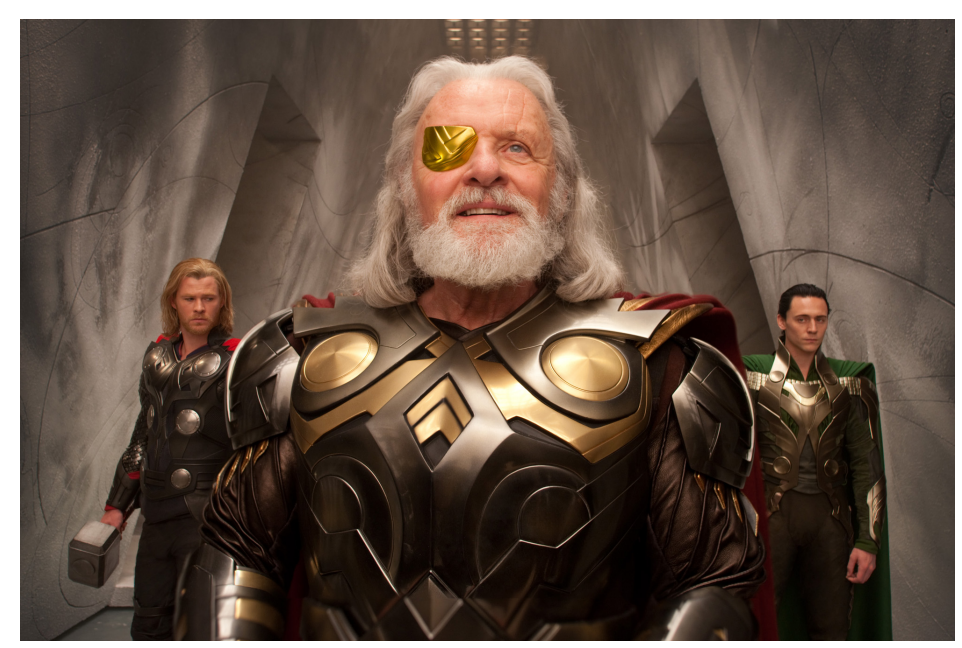

A Thorban Asgard - Odin szavaival - „reménysugár, mely átragyog a csillagok között”; vajon ez a 21. század eleji Egyesült Államok allegóriája? 
Az Asgardba való visszatérésükkor apa és a fia nézeteltérése ismét kiújul, amikor Thor így szól Odinhoz: „Nem lesz mit megvédeni, hogyha félsz cselekedni! A Jöttunöknek félniük kell tôlem is, ahogy régen tôled féltek!" Odint elborzasztja Thor viselkedése, és úgy dönt, hogy megfosztja hatalmától, szeretett kalapácsától, a Mjölnirtôl, és számúzi ôt a Földre. Amit a Thor színre visz, az ugyan nyilván nem pontosan a két Bush, apa és fia kapcsolata vagy az iraki háború valódi motivációja, a közönség nagy része azonban kétségtelenül így látta, és valóban így jelenik meg mind Oliver Stone $W$.-jében (2008), mind pedig Jacob Weisberg bestsellerré vált $A$ Bush-tragédiá jában (2008) is. ${ }^{[10]}$ Mint Darren Franich megjegyezte: „A Mennydörgés Istene a háborús uszítás klasszikus módszerével megtámad egy országot, amelyrôl nem tud semmit; az idôsebb generáció azonban megdorgálja, hogy megtanulja, milyen következményekkel járnak a cselekedetei” (2013). [ $\left.{ }_{11}\right]^{1}$

A 09/11 utáni idôszakban meglehetôsen megszokott volt, hogy a Bush-adminisztráció és gyakran maga George W. Bush is allegorikusan megjelenjen a korszak film- és televíziós szövegeiben, a Csillagközi romboló (Battlestar Galactica. Glen A. Larson, Ronald D. Moore, 2004-2009) címú sci-fi sorozattól kezdve (lásd Kaveney és Stoy 2010), Oliver Stone Nagy Sándor, a hódítóján (Alexander. Oliver Stone, 2004; lásd Jenkins 2015: 120-1) és a Fürész franchise-on át (lásd Kellner 2009: 7-9.) egészen a zombi-apokalipszis utórezgéseiig George Romero Holtak földje (Land of the Dead. George Romero, 2005) (lásd McSweeney 2010) címú opuszában. Ami a szuperhốsmúfajt illeti, Justine Toh a Batman: Kezdôdik!-et (Batman Begins. Christopher Nolan, 2005) nem csupán a Bushkorszak, hanem személy szerint George W. Bush allegóriájának tekintette: „Innen nézve Batman igazságtévő küldetése, hogy megtisztítsa Gothamet a korrupt elemektôl, annak fiktív visszaigazolása lesz, ahogyan az USA munkálkodik a közel-keleti demokrácia elômozdításán.” (2010: 132)

A földre számúzve Thor az új-mexikói Puente Antiguo városában találja magát, ami éppoly hirtelen vet véget kiváltságos életének, mint ahogyan ez Tony Starkkal a Vasemberben (vagy Bruce Bannerrel A Hihetetlen Hulkban (The Incredible Hulk. Louis Leterrier, 2008) történt. Itt kell megtanulnia, mit jelent az alázat, s hogy mi tesz valakit valódi hôssé az olyan emberek között, mint például a két tudós, Jane Foster és Erik Selvig - akik kezdetben s nem meglepó módon nem hiszik el, hogy Thor egy északi isten lenne. Amikor Thor rájön, hogy a Mjölnir a közelben van, amit a Vasember 2 végén látható teaser már megszellôztetett, meggyőződésévé válik, hogy ha újraegyesül a mitikus kalapáccsal, képes lesz kivágni magát a bajból, ahogy mindig is tette élete során. A Mjölnirt a S.H.I.E.L.D. ôrei vigyázzák Phil Coulson ügynök vezetése alatt (akit Thor „Coul fiának” nevez), míg felülrốl Sólyomszem (Jeremy Renner) tartja szemmel. Thor mennydörgés és villámlás kíséretében tör utat a kalapácshoz, mialatt a zeneszerzô Patrick Doyle zenekara diadalmas crescendóba megy át - csak hogy kiderüljön, hogy Thor nem tudja felemelni a Mjölnirt, és hogy még meg kell értenie, mi is volt apja leckéjének üzenete. Látszólag lemondva sorsának irányításáról átadja magát a S.H.I.E.L.D.-nek és Coulsonnak, aki azonnal azt feltételezi, hogy amerikai, és megkérdezi, hol kapott kiképzést: „Pakisztánban, Csecsenföldön, Afganisztánban?”. Miközben fogságban van, megjelenik testvére, Loki, aki közben elfoglalta az asgardi trónt, és 
elmondja Thornak, hogy apjuk meghalt, és hogy Thor soha többé nem térhet vissza Asgardba. Loki az apja döntését egy meglehetôsen evokatív gondolattal magyarázza: „A népnek csakis a folytonosság nyújt biztonságot ezekben a nehéz idôkben."

Miután tehát kellôen megalázták, Thor romantikus érdeklődése új tárgyának, Jane-nek és barátjának, Eriknek köszönhetôen rájön, hogy az igazi erố nem csak a fizikai bátorságon alapul, és amikor Loki elküldi a Pusztítót Puento Antiguóba, hogy egyszer és mindenkorra megölje Thort, összecsapásuk koreográfiája olyan westernek leszámolásjeleneteit idézi, mint a Délidô (High Noon. Fred Zinneman, 1952), a Jó, a rossz és a csúf (The Good, the Bad and the Ugly. Sergio Leone, 1966) vagy a Chisum (Andrew V. McLaglen, 1970), amelyek mindegyike - nem véletlenül - szintén ÚjMexikóban játszódik. Thor, akinek korábban semmi gondja nem volt azzal, hogy egy egész fajt kiirtson, mások életét ezúttal a sajátja elé helyezve segít kimenekíteni a városból az ártatlanokat, és testvérének is így könyörög: „Bármit is tettem ellened, ôszintén sajnálom. De ezek itt ártatlanok. Nem nyersz semmit, ha megölöd óket. Engem ölj meg, és akkor vége.” Thor ajánlata, hogy feláldozza magát, természetesen jól ismert konvenció a nyugati tömegkultúrában, és a MCU-ban is gyakran visszatérnek hozzá, bár nagyon ritkán jár náluk tényleges áldozattal. ${ }^{[12]} \mathrm{Ami}$ azt illeti, ez a krisztusi jellegú önfeláldozás olyan gyakran fordul elô az amerikai filmben, hogy annak az egyik alapvetô trópusává vált. A hozzá kapcsolódó értékítélet azonban problematikus, minthogy a Másik semmiben sem különböző önfeláldozásait szörnyưnek és embertelennek nyilvánítják. A Pusztító általi „halála” és az azt követô újjászületése, különösen a formanyelvi megoldások révén, Thor karakterét a kortárs amerikai tudományos fantasztikus és fantasy-film többi krisztusi figurája mellé helyezi, mint amilyen például Neo a Mátrixból (The Matrix. Lana Wachowski, Lilly Wachowski, 1999), Gandalf a Gyúrük Ura-trilógiából (Peter Jackson, 2001-3), vagy épp E.T. az E.T: A földönkivülibool (E.T. The Extra-Terrestrial. Steven Spielberg, 1982) és James Cole a 12 majom ból (12 Monkeys. Terry Gilliam, 1995). Adele Reinhartz szerint ez a minta olyannyira elterjedt, hogy „minden film, amelynek fớ témája a megváltás (és ez sok, ha nem egyenesen a legtöbb mostanában készült hollywoodi filmre igaz), valószínúleg valamilyen Jézus-szimbolizmust is a megváltó hőshöz kapcsol” (2003: 189). Ami meglehetôsen ironikus, ha meggondoljuk, hogy Thor valóban isten, és a norvég mitológia szerint megelózi Jézust (lásd Lindow 2002: 22), amellett, hogy az MCU felépítésében tudatosan is világi beállítottságú, és csak futó utalásokat tesz a zsidókeresztény Istenre. Azoknak, akik vallásos jelentést kerestek a franchise-ban, elsôsorban ilyen utalásokra és allúziókra kellett támaszkodniuk a karakterek vagy a szöveg által kínált explicit állítások helyett (lásd McAteer 2016; Saunders 2016). A Lokit játszó színész, Tom Hiddlestone szerint ez a többértelmúség lehet az egyik oka annak, hogy a mai szuperhősfilmek nemcsak az azokat nemzô és kitermelô Egyesült Államokban, hanem a globális kultúrában is visszhangot keltenek: „A szuperhősfilmek egy közös, hit nélküli, modern mitológiát kínálnak, amelyen keresztül ezek az [emberi létállapotról szóló] igazságok felfedezhetốk. Ebben az egyre világibbá váló társadalomban, ahol oly sok különféle isten és különféle vallás létezik, a szuperhôsfilmek egy olyan egyedülálló vásznat kínálnak, amelyre minden közös reményünk, álmunk és apokaliptikus rémálmunk kivetíthetố és lejátszható" (2012). Odin mély álmában, a távoli Asgardból is megérzi fia színeváltozását, egyetlen könnyel reagál - s ez a könnycsepp nemcsak hogy életre kelti Thort, de 
általa visszanyeri korábbi erejét s a felhatalmazást is, hogy újra forgathassa Mjölnirt.

Mint korábban említettem, Thor kétségtelenül azon acélos testú hôstípushoz tartozik, amely Jeffords szerint meghatározta az 1980-as éveket, és bár talán a férfiasság egy tradicionálisabb válfajához való visszatérést jelent, mint amilyet Peggy Noonan és Kim DuToit írók kívánatosnak tartanának, Chris Hemsworth karakterábrázolása ezt a hipermaszkulin fellépést alapvetôen tökéletlennek mutatja, ami feltárja az új évezredbeli férfiasság bonyolult és gyakran paradox jellegét. Thor bátran cselekszik, harcos és védelmező, ám kezdeti magabiztosságát és az erőszakra való hajlamát a film egyértelmúen hübrisznek tekinti, és az önismeret hiányával kapcsolja össze. Thort (Tony Starkhoz hasonlóan) csak epifániáját követôen mutatja fel számunkra a film valódi hősként, amikor képes - történelmileg nőiesként kódolt, s így az akcióhősök számára hagyományosan elfogadhatatlan módon - együttérzést mutatni. Az akciófilmek távolról sem egyszerúen „buta filmek buta embereknek” (Tasker 1993: 6), kódjaik és konvencióik, amelyek a szuperhôsfilmeket is mélyen átjárják, látványos kulturális barométert kínálnak számunkra. Míg az 1980-as években az idealizált férfiasság Sylvester Stallone, Arnold Schwarzenegger és Chuck Norris figuráiban, majd a 90-es években Johnny Depp, Brad Pitt és Keanu Reeves férfitípusaiban öltött testet, a Chris Hemsworth, Chris Evans, Chris Pratt és Robert Downey Jr. képviselte új csillagok felemelkedése - akiknek mindegyike egy-egy MCU-filmben is játszott ebben a korszakban - egy korábbinál összetettebb, ám még mindig hegemón férfiimázst kínál az új évezred elsô évtizedeiben.

A Thor és Loki közötti harc csúcspontján Thor új emberként tér vissza Asgardba. Loki éppen azt tervezte, hogy szörnyú népirtást követve el saját fajtája ellen megöli biológiai apját, Laufey-t és a Jégóriások teljes népét, s mindezt azért, hogy méltó örökösnek bizonyuljon mostohaapja, Odin elôtt. Lokinak azonban még meg kell tanulnia azt a leckét, amelyet Thor a Földön kapott, nevezetesen, hogy bár a hatalmuk óriási és gyakorlatilag halhatatlanok, az asgardiak nem természettôl felsôbbrendúek az emberekhez vagy más fajokhoz képest. Loki hasonló kérdést intéz Thorhoz, mint amit Rhodes intézett Starkhoz annak afganisztáni epifániája után: „És hogyhogy most már szereted a Jégóriásokat?” Az MCU-ban többször is feltesznek ilyen kérdést azok, akik még nem tapasztaltak meg olyan sorsfordító, traumatikus eseményt, amely lehetôvé teszi számukra, hogy az együttérzést és az empátiát ne gyengeségként, hanem erôként fogják fel, ugyanakkor viszont egyre-másra gyôzik le a szinte mindig nagyon leegyszerúsített formában ábrázolt ellenséget. Miután Loki kimondatlanul is nemi erôszakkal fenyegeti meg Jane Fostert („Talán, ha itt végeztünk, meglátogatom magam is!”), Thor legyôzi ôt - ami azért érdekes, mert a viszonyuk éppúgy megváltozott (amivel a MCU ezután is küzd majd), mint a Thor harci módszere és látásmódja, amit a film azzal jelez, hogy Thor nem használja a kalapácsát a testvére ellen, és nem támad, csak védekezik. Miután vereséget szenvedett, és „apja”, Odin egyetlen elutasító, néma gesztussal megtagadta, Loki utolsó dacos cselekedete az, hogy a segítséget elutasítva elengedi Odin lándzsáját, és kizuhan a kozmoszba, egy bizonytalan jövô felé.

Mint sok más szuperhôsfilm ebben a korszakban, a Thor a valóság fantasztikus újragondolását nyújtja: míg a Vasember humanitárius vállalkozásként írja át az afganisztáni konfliktust, a Thor egy 
hiú és ingerlékeny vezetôt mutat be, aki felismeri a hibáit („fordítva van, mint hittem, rosszul tudtam mindent”). Thor második áldozata nem más, mint hogy eldobja a saját boldogságát, csak hogy megmentse a Jégóriások faját, akiket valaha úgy megvetett - megmentésük érdekében megsemmisíti a Bifrost-hidat, s így talán soha nem lesz képes visszatérni a Földre szerelméhez, Jane Fosterhez. Ez az altruista gesztus központi szerepet játszik az amerikai monomítoszban, amelybe beleivódott az az elképzelés, miszerint az amerikai háborúkat és külföldi beavatkozásokat soha nem önzô okokból, hanem csakis az emberiség érdekében indítják el, s hogy a globális szuperhatalom olyan felelôsség terhét veszi ezzel a vállára, amelyet senki sem tud igazán felérni ésszel (lásd Colucci 2008). Azok a leckék, amelyeket Thor az elbeszélés folyamán megtanul, nagy segítségére lesznek a Bosszúállókban rá váró apokaliptikus csatában - a filmben testvére, Loki is visszatér, s nem kis szerepet játszik. Thor érzelmi fejlôdése azonban ebben a filmben és a második szólófilmjében a Thor: A sötét világban is folytatódik; karakterét nem „állítják vissza”, ahogy Tony Stark esetében láttuk (és továbbra is látni fogjuk). Noha Martin Arnold nem alaptalanul vetette fel, hogy az új évezred elsô évtizedének végére „a mennydörgés istenének recepciótörténete elérte azt a pontot, amelyen túl már nincs értelme továbbfúzni azt” (2011a: 160), Thor mégis éppen ebben az idôszakban születik újjá amerikai ikonként, s lesz az egyre fejlôdő Marvel-moziuniverzum egyik kulcsszereplője.

$[\ldots]$

\section{„Meséltél apukádnak rólam?”: A nók problémás ábrázolása a Thor: Sötét világban}

[...] A nốk a Marvel-moziuniverzum felépítésének elsô és második fázisában nagyon kis szerepet játszottak a filmekben. A nôi karakterek ritkán kapnak helyet a sorozat privilegizált és dinamikus színtereiben, ehelyett gyakran a perifériára szorulnak, legrosszabb esetben pedig tárgyiasítva, átszexualizáltan és infantilisként ábrázolják ôket. A progresszivizmus felszínes látszatát kelti, amikor a nôk komoly beosztást vagy foglalkozást kapnak: a Vasember-trilógiában Pepper Potts a Stark Industries vezérigazgatója lesz; A Hihetetlen Hulkban megtudhatjuk, hogy Betty Ross neves sejtbiológus; a Thor Jane Fostere pedig híres asztrofizikus - amit néhányan, tévesen, a nôk pozitív reprezentációjaként azonosítottak. Bár leírásaik alapján ezek a szakmák akár alkalmasak is lehetnének arra, hogy jelentôséggel ruházzák fel képviselôiket, a narratívák kibontakozásakor ezek a nôk mégis ritkán kapnak lehetôséget arra, hogy eszükkel és egyéniségükkel demonstrálhassák rátermettségüket - a filmek alapján inkább úgy tûnik, hogy társkapcsolataikat leszámítva súlyosan beszúkült életet élnek, partnereik neve pedig mindhárom esetben egybeesik a bemutatott filmek címével. Hiába mondja el Pepper Pottsról Tony Stark, hogy ô felelôs „a Föld legnagyobb technológiai konglomerátumának" múködéséért (Bosszúállók: Ultron kora. Avengers: Age of Ultron. Joss Whedon, 2015), ha a filmek során aztán nem tesz sokkal többet annál, minthogy reagál az ốt idônként megmentô Vasember tetteire. Betty Ross állítólag ragyogó tudós, Joseph Walderzak pedig „hősnek, partnernek” nevezi (2016: 159), a filmben azonban soha nem végez semmilyen 
lényeges kutatást, többször is megmentőre szorul $A$ Hihetetlen Hulkban, és úgy tünik, hogy Bannerrel, az apjával és a barátjával, Leonard Simsonnal fennálló kapcsolatain kívül mintha nem is létezne. A fenti, valamelyest fontosabb karakterek mellett az MCU nói mellékszerepeiben egyremásra bukkannak fel olyan figurák, amelyeket még rosszabb bánásmódban részesítenek. Christine Everheartra a Vasemberben és a Vasember 2-ben Pepper „szemétként” utal, Stark meg azt mondja rá, hogy „Készítsünk egy darabot a Vanity Fairbe”, miközben az ô szexuális kicsapongását persze ünnepli a film; az Amerika kapitány: Az elsó bosszúállóban (Captain America: The First Avenger. Joe Johnston, 2011) egy gyönyörú katonanő (Lorraine szerepét Natalie Dormer játssza) azt mondja a Kapitánynak, hogy „Önnek Amerika összes asszonya hálával tartozik... és mivel ók nincsenek itt...” - s azzal behúzza egy könyvespolc mögé, hogy megcsókolja. Az a tény, hogy ezek a mintázatok ilyen elterjedtek a valaha volt legsikeresebb filmfranchise-ban, aggasztó, de ennél is nyugtalanítóbb, hogy egyben a kulturális reprezentáció az új évezred első évtizedeire jellemzô, szélesebb körû tendenciáinak a részei, amelyek ráadásul politikai progresszivizmusukkal kérkednek.

Természetesen vannak komplikáltabb esetek is az MCU egészét tekintve, például Peggy Carter ügynök az Amerika kapitány: Az elsố bosszúállóban, vagy Maria Hill a Bosszúállókban, Gamora $A$ galaxis ốrzôiben (Guardians of the Galaxy. James Gunn, 2014) és persze Natasha Romanoff, más néven a Fekete Özvegy, aki a Vasember 2-ben jelent meg elôször, mielôtt Bosszúállóvá vált volna. Peggy Carter ugyan magával ragadó karakter, de a rá jutó korlátozott képernyôidô és az a tény, hogy csak Steve Rogersszel és az ő történetével kapcsolatban kap létjogosultságot, azzal jár, hogy karakter a filmben nem képes annyit fejlódni, mint a Marvel televíziós sorozatában, a Carter ügynök ben (Agent Carter. Fox 2015-16). A galaxis ốrzöinek Gamorája találékony és kemény, de annak ellenére, hogy „éló fegyvernek” hívják, Peter Quill többször is megmenti a filmben, amely kétségkívül Quill története, nem pedig bárki másé. Az MCU elsô és második fázisának négy filmjéből a Fekete Özvegy áll a legközelebb ahhoz, hogy központi nôi karakternek tekinthessük, de még az ô ábrázolása is hangsúlyozza a látszólagos hatalommal felruházott nôk ellentmondásosságát a múfajban. A filmek Natashát fizikailag és szellemileg is rátermettnek mutatják, ô az, aki leállítja a Tesseractot a Bosszúállók végén, és ugyanebben a filmben Sólyomszemet is legyốzi, mégis mind fizikai, mind pszichológiai és érzelmi szempontból sebezhetôbbnek ábrázolják, mint a csapattársait. A Bosszúállókban a Kapitány pajzsa óvja meg, amikor egy autó felrobban New York utcáin, míg Sólyomszem képes gyorsan fedezéket találni egy autó mögött, és ô az, aki nyöszörögve lapul meg, amikor elôször kerül szembe Hulkkal, ami nem jellemző a többi Bosszúállóra. Ahogy Jeremiah Favara írja: „Idônként azt mutatják, hogy a Fekete Özvegy képes megvédeni magát, sốt; kiüti Sólyomszemet, becsapja Lokit, és ô az egyetlen bosszúálló, aki képes az idegen technológiákat kiaknázni a végsô küzdelemben. Máskor viszont sebezhetố és védelmet igényel; amikor például Hulkkal találkozik, tehetetlen, és Thor csak az utolsó pillanatban tudja megmenteni” (2016: 179). A Bosszúállók érdekes utalásokat tesz a Fekete Özvegy múltjára, ám ezek megmaradnak utalásoknak, mivel a karakter nem kapott szólófilmet az elsô, a második és a harmadik fázis során sem. Még a filmmegjelenésein belül is egyre marginalizálódik, illetve idônként problémák merülnek fel karakterének fejlódésével kapcsolatban 
(lásd például a kényszersterilizálás kérdését a Bosszúállók: Ultron korában), a harci jeleneteit pedig olyan módon szexualizálják, ahogyan a férfiak esetében soha nem történik (lásd Purse 2011b). Mint Sherry Ginn A Marvel Fekete Özvegye - kémtôl a szuperhösig: esszék egy nagyon specifikus készségekkel biró bosszúállóról címú kötet szerkesztôje felvetette, továbbra is ô a legmeghatározóbb az MCU nôalakjai közül, és annak ellenére, hogy az MCU-ban szereplő karakter „nem mentes a hibáktól (...) mégis olyan tulajdonságokkal rendelkezik, amelyek önmagában is szuperhőssé teszik.” (2017: 4)

Érdemes lehet ezen a ponton röviden áttekinteni az MCU-ban szereplô nôk életkorát és összevetni azt a férfi társaikéival, mivel ezek az adatok a férfi és nôi előadómúvészek közötti egyenlootlenség folytatólagosságát mutatják, amely az amerikai filmipart évtizedek óta jellemzi. A legszánalmasabb példa erre talán Sean Connery és Catherine Zeta Jones hírhedt romantikus párosítása a Briliáns csapdában (Entrapment. Jon Amiel, 1999), ahol a színészek életkora közt harminchét év az eltérés, vagy Cary Grant és Audrey Hepburn kettôse az Amerikai fogócskában (Charade. Stanley Donen, 1963) a maguk huszonöt évnyi korkülönbségével; huszonhét év választja el Harrison Fordot és Anne Heche-t a Hat nap, hét éjszaka szereplőit (Six Days Seven Nights. Ivan Reitman, 1998), míg Annabelle Wallis huszonkét évvel fiatalabban játszik együtt Tom Cruise-zal a Múmiában (The Mummy. Alex Kurtzman, 2017). Nem izolált esetekról van szó: ezek annak a tendenciának a megnyilvánulásai, amely a médium születése óta meghatározta Hollywoodot (lásd Herman és Sender 2015). Az MCU-ban Edward Norton (született 1969-ben) nyolc évvel idôsebb, mint Liv Tyler (született 1977-ben); Mark Ruffalo (született 1967-ben) tizenhét évvel idősebb, mint Scarlett Johansson (született 1984-ben); Paul Bettany (született 1971-ben) tizenhét évvel idôsebb, mint Elizabeth Olsen (született 1989-ben); Paul Rudd (született 1969-ben) kilenc évvel idôsebb, mint Evangeline Lilly (született 1979-ben), Chadwick Boseman (született 1976-ban) hét évvel idôsebb, mint Lupita Nyong'o (született 1983-ban). Robert Downey Jr.-t (született 1965-ben) a filmben összehozták már Gwyneth Paltrow-val (aki hat évvel fiatalabb, született 1972-ben), Leslie Bibb-bel (kilenc évvel fiatalabb, 1974-ben született) és Rebecca Hall-lal (tizenhét évvel ifjabb, 1982-ben született), de karaktere kapcsolatot kezdeményezett Kate Maráéval (huszonkét évvel fiatalabb, 1983-ban született) és Scarlett Johansonnal is (huszonegy évvel ifjabb, 1984-ben született). Elvétve akadnak kivételek, s a korkülönbség ott is csekély: Natalie Portman (született 1981-ben) két évvel idősebb, mint Chris Hemsworth (született 1983-ban), Hayley Attwell (született 1982-ben) egy évvel idôsebb, mint Chris Evans (született 1981-ben), Zoe Saldana (született 1978-ban) pedig egy évvel idôsebb Chris Prattnél (született 1979-ben).

Ez az eltérés már abban is jelentkezik, hogy a színészek milyen idôs korukban kezdték játszani a karakterüket a sorozatban: Robert Downey Jr. negyvenhárom éves volt, amikor 2008-ban először volt Vasember, Paul Rudd pedig negyvenöt, amikor a Hangyát játszotta 2014-ben. Don Cheadle negyvenhat éves volt a Vasember 2 idején 2010-ben, Edward Norton harminckilenc éves volt A hihetetlen Hulk címszerepében 2008-ban, míg Mark Ruffalo negyvenöt évesen játszotta ugyanezt a szerepet a Bosszúállókban 2012-ben; Chris Evans harmincéves volt az Amerika kapitány: Az elsố bosszúálló 2011 idején. Az egyetlen színész, aki az MCU első fázisában a húszas éveiben játszott szuperhőst, Chris Hemsworth volt, aki huszonkilenc éves volt a Thorban 2011-ben. Mivel az MCU 
első és második fázisában egyetlen nô sem volt címszerepben, az összehasonlítás ezúttal kicsit bonyolultabb. Scarlett Johansson mindazonáltal huszonhat éves volt, amikor 2010-ben elôször jelent meg Fekete Özvegyként a Vasember 2-ben. Hayley Atwell huszonkilenc éves volt az Amerika kapitány: Az elsố bosszúállóban 2011-ben, Elizabeth Olsen pedig huszonöt éves volt a Bosszúállók: Ultron kora idején. 2014-ben Zoe Saldana harminchat éves volt $A$ galaxis örzöiben, Karen Gillan pedig huszonhét ugyanebben a filmben. És megjegyzendô, hogy akkor még figyelembe se vettük azoknak a korosodó, de még mindig aktív és férfias patriarchális személyiségeknek a körét, akiket az MCU a közönség számára kínál, mint a Nick Furyt alakító Samuel L. Jackson, aki hatvanéves volt a Vasember bemutatásakor, és a Marvel kapitány idején már a hetvenbe lépett, vagy Anthony Hopkins, aki a Thor idején hetvenöt éves volt, vagy William Hurt, aki ötvennyolc évesen játszott A hihetetlen Hulkban. Ide sorolható Jeff Bridges is, aki a Vasember idején ötvenkilenc éves volt, Stellan Skarsgård, aki a Thor idején hatvan- és Michael Douglas, aki pedig hetvenéves volt $A$ Hangya bemutatásakor. Milyen hasonló korú és hasonlóan dinamikus matriarchális alakokat kínál az MCU az első és a második fázisban a fenti példákhoz mérhetô képernyőidôvel és befolyással? Rene Russo juthat eszünkbe, aki a Thorban Friggát játszotta, s akkoriban ötvenhat éves volt, Jenny Agutter, aki 2012-ben, a Bosszúállókban hatvan volt, vagy Glenn Close, aki ötvennyolcéves volt, amikor Irani Raelt játszotta A galaxis ốrzöiben. Ezek a karakterek azonban távolról sem állnak olyan mértékben a narratívák középpontjában, mint ahogyan Nick Fury, Odin, Thaddeus Ross, Obadiah Stane, Erik Selvig vagy Hank Pym. ${ }^{[13]}$

Egy másik módszer, amellyel egyértelmúvé válik a nôk marginalizálásának mértéke az MCU-ban és általában az amerikai filmiparban, a férfiak vagy a nôk megszólalási gyakoriságának statisztikai elemzése. Számos intézmény és magánszemély végzett kutatást ezen a területen, ezek közül a legjelentôsebbek a Média, sokszinúség és társadalmi változások kezdeményezés címú program az USC Annenbergnél, a Geena Davis Intézet kutatása a média és a társadalmi nemek viszonyáról, illetve a nôk helyzetét a televízióban és a filmben vizsgáló kutatóközpont (Center for the Study of Women in Television \& Film). Eredményeik alighanem kellemetlen olvasmánynak bizonyulnak egy olyan korban, amikor a médiában általános az egyetértés abban, hogy manapság mind a kamera eloott, mind amögött sokkal több szerep jut a nôknek, a feltételezett változás bizonyítékaként pedig olyan filmekre hivatkoznak (lásd Scott és Dargis 2014), mint például a Csillagok háborúja: Az ébredô erố (Star Wars: The Force Awakens. J.J. Abrams, 2015), Az éhezók viadala franchise (2012-15) és a Wonder Woman (Patty Jenkins, 2017). Ráadásul bizonyos körökben mindez olyannyira a visszájára fordult, hogy egyenesen „feminista hatalomátvételt” (Rachel Lefler, 2015) emlegettek. Ezt az elgondolást azonban egyáltalán nem támasztják alá a fent említett tanulmányok megállapításai, amelyek bizonyítják, hogy az efféle állítások inkább anekdotikusak, mint empirikusak. Például az USC Annenberg egy 2017-es tanulmánya, a Kik ülhetnek a rendezöi székbe? A filmrendezók nem, faj és életkor szerinti megoszlása 1000 film vizsgálatával 2007-2016 között arra jutott, hogy Hollywoodban minden egyes nôi rendezôre huszonnégy férfi rendezố jut, a nôi rendezôk karrierje nem olyan hosszú, mint a férfiaké, és a múfajok közül szinte kizárólag drámát rendezhetnek (lásd Smith et al., 2017). Ami a kamera túloldalát illeti, a kutatások azt mutatják, hogy az év száz legfontosabb filmjének átlagát figyelembe véve a nôkre csak a beszédet kívánó szerepek kb. 28-33\%-a jut; ha 
pedig csak az akció és a kaland múfaját nézzük (ahová a szuperhôsfilm is tartozik), ez az arány 20\%ra csökken (lásd Smith et al. 2015a). A nôk sokkal gyakrabban viseltek szexis ruhát, mint a férfiak (a nôk 27,9\%-a, szemben a férfiak 8\%-ával), szerepeltek ruhátlanul (a nôk 26,4\%-a, szemben a férfiak 9,1\%-ával), vagy utaltak rájuk fizikailag vonzóként (a nôk esetében 12,6\%-ban, szemben a férfiak 3,1\%-ával) (lásd Smith et al. 2015b). Ha az általános tendenciák szemléltetéseként kiválasztunk egy konkrét évet, 2015-öt, amikor az MCU bemutatta a Bosszúállók: Ultron korát és $A$ Hangyát, azt látjuk, hogy a száz legnagyobb bruttó bevételú filmben a férfi karakterek körülbelül kétszer annyit szerepeltek a képernyőn, mint a nók (28,5\% a 16\%-hoz képest), a főszereplók $71 \%$-a férfi volt (a nôkre így $29 \%$ jutott), a rendezók közül pedig csak 4\%, az írók közt 11\%, a filmkészítók közt 3\%, a producerek közt 19\%, a szerkesztôk közt pedig 14\% volt nő (lásd Lauzen 2016). Továbbá a 2015-ben elkészített MCU-filmek még a közelébe sem érnek a fenti 28-33\%-os átlagos aránynak, ami a nôi szereplőkre osztott, szöveggel járó szerepeket illeti, ahogyan az első vagy a második fázisban készített filmek egyike sem éri el ezt a küszöböt, s egyedül a Vasember 3-ban jutnak szóhoz több mint 25\%-ban a nôi karakterek. A beszélô női szereplők alacsony arányának különösen elképesztô példái az elsô fázisban $A$ hihetetlen Hulk (12,2\%) és a Thor (15\%), valamint a második fázisban $A$ Hangya (14\%) és kissé meglepô módon A galaxis ôrzői (10,7\%), mely utóbbi a két fázis filmjei közül a legalacsonyabb százalékot hozza. ${ }^{[14]}$ A hihetetlen Hulk 112 perces vetítési ideje alatt csak öt olyan nôt szerepeltet, aki egyáltalán megszólal, s közülük is csak három túnik fel névvel a stáblistán: Betty Ross, Martina (egyetlen portugál mondattal, és az sincs lefordítva), Kathleen Sparr ôrnagy, egy névtelen nô, aki ruhákat árusít a piacon, és egy szintén megnevezetlen hírolvasó. Mielôtt erre egyszeri eltévelyedésként tekintenénk, érdemes figyelembe venni, hogy a Thorban is csak Jane, Darcy, Sif, Frigga és két névtelen nôvér beszél, míg a Vasemberben $(19,1 \%)$ a nyolc megszólaló nő közül csak ötnek - Peppernek, Christine Everheartnak, Ramireznek (ő a Humvee-ban ülô katona a film elején) és két televíziós hírolvasónak, a valós Zoriana Kitnek és a kitalált Amira Ahmednek van neve (a három másik nô közül kettô stewardess, egy pedig anya Gulmirában). Az Amerika kapitány: Az elsố bosszúállóban (17,5\%) pedig összesen két olyan nô van, akiket a képernyôn egyáltalán megneveznek: Peggy Carter ügynök és Mandy, a hostess a Holnap világa címú kiállításon, aki egy árva szót sem beszél.[15]

A most következó rész ebben a kontextusban próbálja feltárni Natalie Portman Jane Fosterének a Thor és folytatása, a Thor: Sötét világ közötti átalakulását, ami akár magyarázhatja Portman 2016-os megjegyzését is, miszerint „végzett” a Marvel Moziuniverzummal (lásd Han 2016). A Hollywood Reporter arról számolt be, hogy az Oscar-díjas múvész elégedetlen volt azzal, hogy a film eredeti rendezôjét, Patty Jenkinst eltávolították a projektből, és ahogy a film alkotói iránya ennek eredményeként alakult (lásd Masters 2011). Jenkins lett volna az MCU elsô nôi rendezője 2013-ban, sôt, az elsố nő, aki szuperhôsös kasszasikert rendez, amit négy évvel késôbb aztán meg is tett, amikor 2017-ben átvette a DCEU kritikai és kereskedelmi szempontból is sikeres Wonder Woman jének levezénylését. A Thor: Sötét világ DVD-kommentárjában az ốt felváltó Alan Taylor kijelentette: „Natalie karaktere valami frisset ad a hôsnô képéhez. Ô egy intelligens tudós”; Kevin Feige pedig hozzátette: „Előreviszi a cselekményt, tényleg az akció részévé válik”, ám ezeket az állításokat a filmek nem igazolják, ami kitûnő példája a nôk MCU-beli megkérdôjelezhetô 
ábrázolásának. A sorozat tehát felszínesen azt a képzetet kelti, mintha hatalmat adna a nôknek, pedig valójában a marginalizálásukat és a tárgyiasításukat segíti elô, és ezáltal a heteronormatív patriarchális kultúra és az ahhoz társuló konzervatív értékek megerôsítéseként szolgál.[16]

A Thor: Sötét világ, amelyet 2013 októberében mutattak be, egyszerre a Kenneth Branagh által rendezett Thor és a Bosszúállók elbeszélésének folytatása, s azzal kezdôdik, hogy Lokit láncra verve hozzák vissza Asgardba, miután New York chitaurik általi megszállása sikertelennek bizonyult. Bemutatásakor a film vegyes fogadtatásra talált, s több kritika Mick LaSalle azon hozzászólását visszhangozta, miszerint „A nagyobb nem mindig jobb. A Thor: Sötét Világ felpörgeti az akciót és a speciális effektusokat, de elveszíti az emberi tényezôt, amely az eredeti Thort érdekessé tette" (2013), vagy Amy Nicholson azon állításához csatlakozik, miszerint „Mivel Thorból hiányzik a Vasember szelleme, Hulk agya és a Kapitány eszményei, az a veszély fenyegeti, hogy hülyét csinál magából, ha a franchise nem tudja kitalálni, mit kezdjen a leglátványosabb hôsével” (2013). A filmre széles körben az MCU egyik leggyengébb teljesítményeként tekintenek, bár ennek ellenére - főként Tom Hiddlestone folyamatos jelenlétének köszönhetôen, aki ezúttal már a harmadik alkalommal játszotta Lokit - jelentôs rajongótábora van. ${ }^{[17]}$ A Bosszúállók és a Thor: Sötét Világ közti idôszakban Hiddlestone még inkább megkedveltette magát az MCU-rajongókkal, amikor a 2013as Comic-Con-on teljes Loki-kosztümben jelent meg, és az alkalomhoz igazítva vidáman elôadta a Bosszúállókból leggyakrabban idézett (és mémesített) monológjait:

Emberiség... lásd, hová fajultál. Órákig álltok sorba a tikkasztó hôségben... Összebújtok a sötétben... Mint a barmok! Loki vagyok, az utolsó isten - és fennkölt céllal érkeztem a Földre. Álljatok félre, nyavalygó férgek. A szabadság csalfa fénye mindig megmérgezi a boldogságotokat, mert ott a vágy, hogy helyet kapjatok ebben a csarnokban. Ebben a szerény midgardi palotában, a H. teremnek hívott arénában. Hol vannak most a Bosszúállóitok? Mondjátok ki a nevem!

A Thor bemutatta, hogyan lesz a címszerepló arrogáns és heves ifjúból Asgard trónjának méltó örököse, a Thor: Sötét Világ pedig tovább folytatja ezt a szálat. Az első filmhez hasonlóan ennek is a két testvér, Thor és Loki, valamint az öregedô apjuk, Odin közötti oedipális dinamika az érzelmi központja. Bár Thor mind királyként, mind szülóként elismeri Odin érdemeit, Alan Taylor, akit addig inkább a Trónok harcának rendezôjeként (HBO, 2011-2019), mint a játékfilmes munkái miatt ismertek, egy alternatív perspektívát vetett fel: „Bár Odint a Mindenek Atyja névvel illetik, ő az egyik legrosszabb szülô, akit valaha láttam ... Teljesen tönkretette a gyerekkorukat. Hogy mondhatod azt két fiúnak, hogy mindketten királynak lettek teremtve, de csak az egyik fogja megkapni a trónt!" (idézi Moore és Javins 2013: 174). ${ }^{[18]}$ A trónt késôbb elpusztítja a film elsôdleges antagonistája, az unalmas és minden árnyalást nélkülözó gonosz, Malekith (Christopher Eccleston), aki a Sötét Elfek leszármazottja - úgy tudni, fajtáját egykor Odin nagyapja, Bors irtotta ki. Malekith sokévnyi számúzetés után most visszatér, hogy bosszút álljon, de semmi olyasmije nincs, ami akár távolról is személyiségre emlékeztetne, még az elôző filmben szereplô Laufey-hez, a Jégóriások királyához viszonyítva sem. A film címe onnan ered, hogy Malekith egy új korszak, a 
sötét világ bevezetésére törekszik, amihez reményei szerint egy Éterként ismert titokzatos anyagot használna fel, amely az MCU-ban szétszórt hat végtelen kô egyike.

Jane Foster, Thor földi barátnóje az, aki véletlenül kapcsolatba kerül ezzel az Éterrel, és ezzel mozgásba hozza a cselekményt. Az elsô filmben Jane az MCU elsô fázisának valamelyest érdekesebb nôi karakterei közé tartozott, különösen Pepper Potts és Betty Ross típusához képest. Megfelelt ugyan a hôst imádó barátnő szerepének, az ügyetlensége pedig kicsit gyerekessé tette, de elkötelezett és tehetséges asztrofizikusként is bemutatták, aki dolgozott és kutatott, Thornak nem kellett ốt megmentenie, és sem a ruhája, sem a viselkedése nem szexualizálta nyíltan. Mialatt Thor két éven át hősies harcokat vív a kilenc birodalom egész területén, Jane-rôl annyit tudunk, hogy javarészt a távollétén bánkódik. Darcy azzal vádolja, hogy „a pizsamádban kóvályogsz nasit majszolva, és megszállottan ábrándozol... tudod, kiról", ami azt sugallja, hogy Jane Thor nélkül képtelen normálisan funkcionálni, folytatni a kutatását vagy akár az életét. Amikor a közönség elôször találkozik vele újra, épp egy randevún van a nagyszerú Richarddal (Chris O’Dowd), miután visszaköltözött Londonba, ám nyilvánvaló, hogy A hihetetlen Hulk Leonard Samsonnal randevúzó Bettyjéhez hasonlóan soha nem lehet elégedett senki mással a film hősén kívül, aki félelmei szerint elhagyta ốt az elsố film eseményei után. Jane nem tudja, amit mi, a közönség tudunk, nevezetesen, hogy a Thor csúcspontján Thor elpusztította a Bifrost-hidat, hogy megmentse a Jégóriások faját Loki népirtásától, ami lehetetlenné tette, hogy visszatérjen hozzá.

Amikor Jane és Darcy elmennek megnézni egy megmagyarázhatatlan „stabil gravitációs anomáliát", egy teherautót találnak a levegốben, amely valamilyen módon fittyet hány a gravitáció törvényének, s ez mindkettôjükben felidézi, amit közvetlenül a Thorral való találkozásuk elôtt éltek át Új-Mexikóban az elsô filmben. Jane arra utasítja Darcyt, hogy ne érintsen meg semmit, ô azonban pontosan ezt teszi, minekutána egy portálon átkerül egy másik világba, és megfertôződik az Éterrel. Úgy túnik, a testén áthatoló titokzatos anyagnak köszönhetôen szuperhatalomra tesz szert, ugyanakkor eszméletét veszti, valahányszor aktiválódik ez az erô, s emiatt több alkalommal hosszú percekig festményszerúen ábrázolt, valódi Csipkerózsikaként idôz rajta a kamera. Emellett, mint az Éter figyelemre méltó erejének hordozója, a film nagy részében Thor és Malekith harcának tárgyává alakul, s az első filmben bemutatott erôt és elszántságot felváltja a „bajba jutott hölgy", akit nemcsak Thornak kell újra és újra megmentenie, amire még számíthatunk, hanem más karaktereknek, például Lokinak, Friggának, de még Erik Selvignek is. Amikor megtudja, mi történt vele, Thor valahogy visszatér a Földre, csak hogy Jane komikus módon kétszer is pofon vágja, miközben azt tudakolja, miért nem jött vissza korábban - egy eset a sok közül, amikor a karaktert elsôsorban az érzelmei határozzák meg, nem pedig az értelme. 


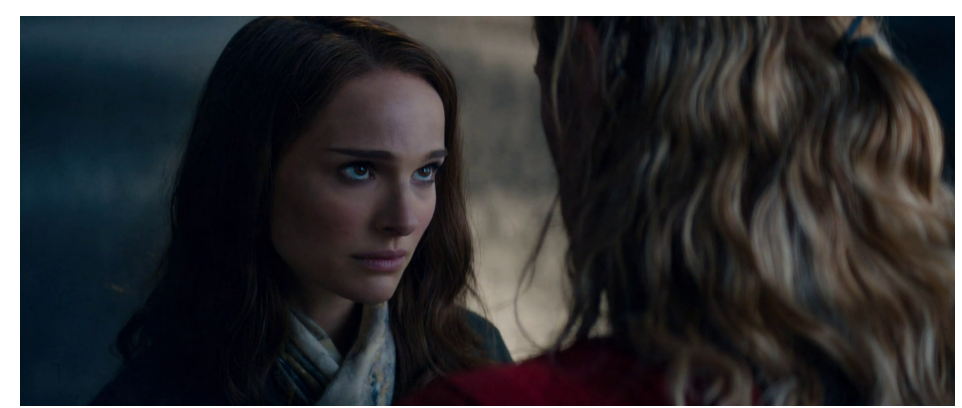

Jane Fostert a Thor: Sötét világ mindvégig tárgyiasitva, marginalizálva és infantilisként ábrázolja.

Az ezt követô, Asgardba vezető útja érdekes módon visszára fordítja az első film „partra vetett hal” történetét, mivel most Asgardot mutatják Jane szemével; Odinról azonban kiderül, hogy kifejezetten elkeseríti a jelenléte. Amikor a hajdan oly határozott és eltökélt nôi tudós meghallja, hogy Thor róla beszél az apjával, elpirul, mint egy tinédzser, és azt kérdezi: „Meséltél apukádnak rólam?” Pedig amikor Odin meglátja ôt, elutasítóan csak annyit mond: „ez a halandó nô annyira illik Asgardba, mint a kecske az elegáns svédasztalhoz", nem zavartatva magát attól sem, hogy Jane a szobában van. Thor így tiltakozik: „nem hinnéd róla, mennyire erôs”, Alan Taylor filmje azonban kevés bizonyítékot szolgáltat erre, Jane-t pedig intelligens és találékony tudósból szeszélyes és érzelgôs barátnôvé alakítja, aki ilyesmiket mond Thornak: „Szeretem, ahogy elmagyarázod a dolgokat!”, a közönségnek meg olyanokat, hogy „a fizika törvényei nem múködnek”. Amikor Thor Asgardba viszi Jane-t, hogy meggyógyítsák, a nézôben az a gyanú ébredezik, hogy Jane szuperhatalmúvá válása szörnyú kilátás - olyannyira, hogy a narratíva minél hamarabb el is kívánja távolítani belôle ezt az erôt, nagyon hasonlóan ahhoz, ahogyan Pepper Pottsot kezelték a Vasember 3-ban, miután megfertôződött az Extremis-vírussal.

Jane nem az egyetlen nôi karakter, aki az eredeti filmhez képest regresszióba süllyedt. Sifet egészen más módon kezelik, mint férfi társait, és a Thor óta ô maga is visszafejlődött. Branagh filmje erôs és független nôként ábrázolta ôt, aki egyértelmúen szerelmes Thorba, de vonakodik ezt kimutatni. A folytatásban Sif és nem a férfi társai azok, aki a film nyitócsatájában Thor szerint nem uralja magát, csak az ô ruhája hangsúlyozza az alakját, és a Thor iránti sóvárgása is sokkal nyíltabb, habár tudja, hogy a férfi másik partnert választott. Ezzel szemben Volstagg például elhízott és komikus, de soha nem gyenge vagy érzelmileg sebezhetố figura, ahogyan Fandral vagy Hogun sem. Az első filmben Thor anyja, Frigga túl gyengének bizonyult ahhoz, hogy a trónteremben kardot emeljen Laufey-ra, a Jégóriások királyára, a folytatásban azonban kap egy hôsies pillanatot, amikor Jane megmentése érdekében szembeszáll Malekith-tel. De meghal, és ezzel azt az ismerôs nối toposzt hozza múködésbe, melynek értelmében a nố halála adja a hôs cselekedeteinek hajtóerejét. Tehát, bár Craig Kyle azt állítja, hogy Frigga „még fontosabb is” (idézi Moore and Javins 2013: 194), mint Odin, ô is azok közé az MCU-beli anyák közé tartozik, akiket az elbeszélés peremvidékére számúz, vagy egyenesen töröl a narratíva.

Frigga halála után Thor és az apja összevitatkoznak azon, hogy mi lehetne a legjobb stratégia a Malekith-tel folytatott küzdelemben, ami határozottan felidézi az elsô filmben bemutatott 
nézeteltérésüket a Jégóriások fenyegetésével szembeni fellépés mikéntjérôl, a szerepek azonban most megfordulnak. Thor az észszerú megfontolás pártján van, Odin pedig azt akarja, hogy maradjanak és harcoljanak „az utolsó asgardi lehelletig!” Thor egyenesen megkérdójelezi apja ítéletét - „akkor miben különböznél Malekithtől?” -, bár a párhuzam hamis, hiszen a gyász sújtotta Odin bölcs és tiszteletre méltó férfinak bizonyult mindkét Thor-filmben, míg Malekith egydimenziós, pantomimszerú gonosztevő. Mindenesetre Thor ismét szembeszáll az apjával, bár ezúttal Asgard érdekében. Ekkor engedi ki Lokit a börtönből, mert a segítségére van szüksége Malekith legyőzéséhez. Amikor Loki találkozik Jane-nel, a nôvel, akit az első filmben kimondatlanul is szexuális erōszakkal fenyegetett, az arcul csapja, ahogyan korábban Thorral is tette: „Ezt New Yorkért adom!” - ami metaforikusan Oszama Bin Laden 9/11 miatti arculcsapásának feleltethetô meg (s amit Amerika kapitány valóban meg is tett a Freedom 3 képregény elsố számában [2006]). Thor tudja, hogy nem bízhat meg az öccsében, de reméli, hogy ôt is hajtja a közös bosszúvágy. Amikor végül szemben találják magukat Malekithtel, úgy túnik, hogy Loki ismét elárulta Thort, akinek levágja a kezét, azt állítva, hogy „nem vágyom másra, csak hogy te és Odin holtan feküdjetek", ám kiderül, hogy ez is a tervük része, és együtt támadják meg a Sötét Elfek vezetôjét. Úgy túnik, Jane-t megrettenti az események ezen fordulata, és éppúgy nem látja át a stratégiát, ahogyan Pepper sem a Vasember 3-ban, amikor a villája elleni támadáskor Tony rá akarja adni a Vasember-ruhát. A csata során Loki az, aki megmenti Jane-t, majd látszólag feláldozza magát a testvére érdekében. Egy könnyfakasztó jelenetben Thor megígéri neki: „Elmondom apánknak, mit tettél ma érte”, de Loki azt mondja: „Nem érte tettem...” Az MCU történetének első és második fázisban Lokié a legrövidebb megjátszott haláleset, mivel három percen belül kiderül, hogy ez is része volt a tervének.

Miután az Étert eltávolították Jane-ból, a nô még a korábbinál is súlytalanabb karakterré válik; a színpad pedig készen áll a londoni Greenwichben játszódó nagyjelenetre, amely az idôvel és a térrel való történelmi kapcsolatai miatt megfelelô helyszínválasztásnak tûnik. ${ }^{[19]}$ Ebben a jelenetben nem Jane lesz Thor fô segítóje, ahogyan az a szakértelmét tekintve várható lett volna, hanem Erik Selvig, akit nemrégiben engedtek szabadon egy pszichiátriai intézményból. Amint Walderzak megjegyzi, „Erik az, aki megérti, és a közönségnek is megmagyarázza a gravitációs konvergenciát, annak ellenére, hogy ez Jane szakterülete" (2016: 160). Jane ugyan részt vesz a greenwichi csatában, és az ô számításai segítenek megfelelôképp elhelyezni a Malekith ellen használt teleportációs eszközöket, ám egy „hoppá!” pillanatot is kap, amikor véletlenül rossz helyre teleportálja Darcyt és Iant (Darcy saját gyakornokát), késôbb pedig, amikor a Sötét Elfek megtámadják óket, Selvignek kell ôt megmentenie. Miután Thornak a galaxis érdekében hozott nemes áldozata révén legyôzik Malekithet, Jane is bemutatja a maga áldozatát, ám teljesen más módon, mint ahogyan azt a férfi hôsök az MCU-ban a Vasember óta filmrôl filmre teszik. Látva, hogy az eszméletlen Thor épp Malekith zuhanó hajójának útjában fekszik, megpróbálja kiszabadítani, de rájön, hogy nem lesz rá képes, ezért úgy dönt, hogy inkább a nagyon is emberi testével védi meg ôt (a halhatatlan istent), mintegy jelezve, hogy hajlandó meghalni a férfiért. Mint várható, az áldozathozatal nem teljesül be, és Jane-t néhány percen belül másodszor is megmenti Selvig, aki okosan arra használja a teleportáló készüléket, hogy Malekith hajóját átküldje egy másik 
világba. Hogy miért nem Jane zsenialitása mentette meg Thort vagy a kollégáit, az nem világos, a film utáni jelenetek egyikében azonban megkapja méltó jutalmát a filmben mutatott magaviseletéért egy szenvedélyes csók formájában, amely a heteronormatív tárgyiasítás egyik legjellemzóbb megnyilvánulásának számít, s amelyet Robin Wood emlékezetes módon a hollywoodi mozi „ideológiai védôbástyájának” nevezett (1998: 37). Végsô csavarként, feleslegességének egy újabb szimbolikus gesztusaként, Jane arcát az ölelkezés alatt elrejtik a kamera elôl, a film audiokommentárjában pedig Alan Taylor rendezố azt is elárulta, hogy Natalie Portman nem is volt jelen a jelenetnél, hanem a közönség tudtán kívül Hemsworth valódi felesége, Elsa Pataky helyettesítette.

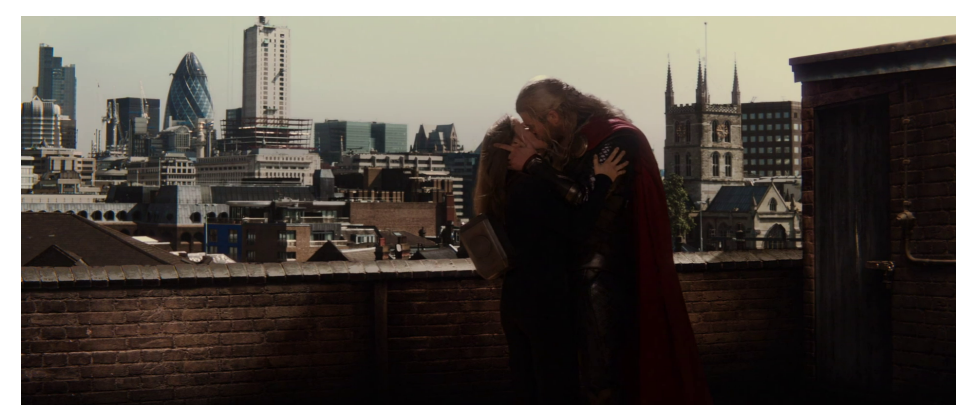

Thor és Jane csókja a Thor legvégén, amikor is a szinésznöt Elsa

Pataky, Chris Hemsworth felesége helyettesitette.
Fordította Hódosy Annamária

\section{A fordítást ellenőrizte Huszár Linda}

[A fordítás az alábbi szövegek alapján készült: McSweeney, Terence: Allegorical Narratives of Gods and Monsters: Thor and The Incredible Hulk és „Nothing's been the same since New York”: Ideological Continuity and Change in Iron Man 3 and Thor: The Dark World. In McSweeney, Terence: Avengers Assemble! Critical Perspectives on the Marvel Cinematic Universe. London - New York, Wallflower Press, 2018. 72-81., 138-149.]

1. Ha másképp nem jelölöm, az idegen nyelvú szövegeket saját fordításomban közlöm. [- $A$ ford. H.A.]

2. A filmekből vett párbeszédek fordításait minden esetben a filmek hivatalos magyar szinkronjához igazítottam [- A ford.].

3. A Marvel A S.H.I.E.L.D. ügynökei címú sorozatának pilot epizódjában (1.01) Grant Ward a következô megjegyzést teszi: „Nem hiszem, hogy Thor technikailag isten”, mire Maria Hill így felel: „Hát, maga nem volt a karja közelében”. Az MCU elsô 15 filmjében a „valódi” istenséghez A galaxis ốrzői 2-ben (Guardians of the Galaxy: Vol. 2. James Gunn, 2017) megismert Ego, az Égi Lény, az Ũrlord apja áll a legközelebb, és még ô is „kis i”-vel jelölné a státuszát.

4. Thor a hidegháború alatt (a Journey into Mystery 117. számában 1965 júniusában) San Diablóba is ellátogatott, amely alig leplezetten Cubát helyettesíti, és egy Castro-szerú gazfickó ellen harcol, akit úgy hívnak, hogy a Hóhér (The Executioner).

5. Megfigyelték, hogy Odin, Loki és Thor verbális interakciói a Marvelben kifejezetten Shakespeare-szerú dimenzióval rendelkeznek (lásd Fingeroth 2004: 37). Sôt, sokan úgy gondolták, hogy pontosan ez az oka annak, hogy a film rendezéséhez Kenneth Branaghot választották. A vele készített interjúkban Branagh 
igyekezett csökkenteni a Shakespeare-kapcsolatok jelentôségét, azok mégis eléggé hangsúlyosnak tûnnek. Shakespeare $V$. Henrikje, amelynek adaptációját Branagh rendezte 1989-ben, saját magával a főszerepben, szinte mintát kínál Thor számára a fiatal királynak az érettség felé vezetô úton megélt próbatételei és gyötrelmei ábrázolásában. Ezzel Anthony Hopkins is egyetérteni látszik, mivel leírásában a mozi „szuperhősfilm, egy kis Shakespeare-rel felturbózva” (idézi Carroll 2010).

6. Érdekes módon az északi mitológiában Laufey Loki anyja, és nem az apja. Ez a változtatás módfelett szórakoztató lehetett Izlandon, ahol a Laufey még mindig meglehetôsen gyakori nôi keresztnév, a film pedig az év legnépszerübb alkotása lett.

7. Laufey sértése szándékos utalás a Frymskviðara, az Edda-énekek egyik versére, amelyben Thornak Freya istennô ruháit kell felvennie, hogy visszaszerezze a Mjölnirt egy óriástól. Thor így panaszkodik: „mind kicsúfoltok és férfiatlannak neveztek majd, ha felveszek egy menyasszonyi fátylat” (Crossley-Holland 1980: 70).

8. 2002-ben George W. Bush állítólag azt mondta Saddam Husseinről: „Végül is ez az a fickó, aki megpróbálta megölni az apámat” (idézi King 2002).

9. A szöveg ezzel Samuel Huntington Civilizációk összecsapása és a világrend átalakulása (1996) címú, rendkívül nagyhatású könyvére utal, amely a 20. század végi és 21 . századi politikai átrendezôdést elemzi, és hipotéziseket alkot annak jövóbeli alakulásával kapcsolatban.

10. Kérdés, hogy vajon véletlen egybeesésrôl van szó, vagy annak bizonyítékáról, hogy a közel-keleti származású színészek számára mennyire nincs szerep - Oliver Stone $W$-jében Sayed Badreya játssza Saddam Husseint, ugyanaz az egyiptomi színész, aki a Vasemberben Abu Bakart alakítja.

11. A Thor the Movie: Politics with a Hammer [„A Thor: Politika egy kalapáccsal”] címú cikkében Martin Arnold egyenesen azt írta a Thorról, hogy „Ebben az esetben a kérdés a nemzet megmentése, vagy másképp fogalmazva, a 21. századi amerikai külpolitika problémái. [...] A történet pedig, mely szerint a fiú ok nélkül megtámad egy országot, mert úgy érzi, hogy származásánál fogva joga van hozzá, hogy leigázza az apját zavaró gonosztevôket, leleményes plusz jelentésréteget kínál a filmben az amerikai külpolitikáról” (2011b).

12. Az MCU kevés valódi áldozata közé számít például Yinsen Ho, aki Tony Starkért áldozta fel magát a Vasemberben, Quicksilver a Bosszúállók: Ultron korában és Yondu Udonta, aki A Galaxis ôrzői 2-ben Peter Quillért adta az életét.

13. Tilda Swinton 55 éves volt, amikor eljátszotta az Ôsmágust a harmadik fázisbeli Doktor Strange-ben, Marisa Tomei pedig 51 volt az Amerika kapitány: Polgárháború idején 2016-ban.

14. Ez tükrözôdik abban is, hogy némelyik MCU-film (például A Hangya, a Bosszúállók, a Vasember, A hihetetlen Hulk, az Amerika kapitány: az elsó Bosszúálló és a Doctor Strange) megbukott a Bechdel-teszten, amelyet Alison Bechdel rajzoló után neveztek el, s ahol az átjutás kritériuma, hogy legalább két megnevezett nôi karakter a férfiakon kívül másról is beszéljen.

15. Referenciaként valószínúleg Patty Jenkins Wonder Womanjéhez kell fordulni, amely bizonyosan több szempontból is megemelte a mércét a múfaj női figuráinak ábrázolásában. A film a nyitó hétvégén 103 millió dollárt keresett, ami a legmagasabb a nôi rendezők között és a női fôszerelôs képregényfilmek között egyaránt. A film a 228 millió dolláros globális nyitó hétvégén többet keresett, mint a két korábbi képregényből készült női szuperhôsfilm, az Elektra (2005; 56 millió dollár) és a Macskanö (2004; 82 millió dollár) együttesen: ugyanakkor még a Wonder Womanről is elmondható, hogy bár egy különösen hosszú, csak nóket szerepeltetô jelenettel kezdődik Themiscyra szigetén, a beszélô karaktereknek csak a 34\%-a nô.

16. Jane Foster felületes jellemzése arra inspirálta Ross Puttman forgatókönyv-olvasót, hogy az ô nevét használja a Twitteren @femscriptintros elnevezésú projektjében. Puttman kiemeli a nôi karakterleírásokat a forgatókönyvekból, az összes nevet „Jane”-re változtatja (az ártatlanok védelmében), majd 140 
karakterenként kiküldi óket. Az eredmény egymondatos, felületes jegyzetek sora, amelyek leírják ugyan a karakterek „külsejét, de ritkán mondanak bármit is róluk” (Watercutter 2016).

17. A Thor: Sötét világ a franchise legrosszabbul fogadott filmje mind a Metacritic, mind a Rotten Tomatoes szerint, amelyet a Vasember 2 követ.

18. A Thor: The Dark World Prelude (2013) képregényben a New York-i csata során Vasember megkérdezi Thort, hogy nézte-e a Trónok harcát. Majd hozzáteszi, hogy „olyan, mint te, csak mágikus pöröly helyett sárkányaik vannak, és szexelnek”.

19. A film véleményem szerint legerôsebb idô- és térbeli anomáliájának ábrázolásával a Thor: Sötét Világ egyike lett annak a pár 2013-ban készült amerikai filmnek, amely a Brit Filmintézettôl „brit” státuszt kapott, miután átment a „kulturális filmteszten”. 2013-ban brit státuszt kapott például a Banks úr megmentése , Az Óriásölö, a Halálos iramban 6, A sötét lovag: Felemelkedés és a Titánok haragja, az akkori BAFTA pedig sokat vitatott módon a Gravitációt választotta az év legjobb brit filmjének.

\section{Irodalomjegyzék}

- Arnold, Martin (2011a): Thor: Myth to Marvel. New York, Continuum.

- Arnold, Martin (2011b): Thor the Movie: Politics with a Hammer. A guest post by Martin Arnold, author of Thor: Myth to Marvel. Bloomsbury History, 05. 23. URL:

https://bloomsburyhistory.typepad.com/bloomsbury-history/2011/05/thor-the-moviepolitics-with-a-hammer-a-guest-post-by-martin-arnold-author-of-thor-myth-to-marvel.html (2019. 12. 16.)

- Burroughs, John (1913): Writings (17. kötet). Boston, Houghton Mifflin.

- Carroll, Sean (2010): From Eternity to Here. London, Oneworld.

- Clarke, Arthur Charles (1973): Profiles of the Future: An Inquiry into the Limits of the Possible. New York, Harper \& Row.

- Colucci, Lamont (2008): Crusading Realism: The Bush Doctrine and American Core Values After 9/11 . Lanham, MD, University Press of America.

- Crossley-Holland, Kevin (1980): The Penguin Book of Norse Myths: Gods of the Vikings. New York, Penguin.

- DuToit, Kim (2013): The Pussification of the Western Male. Common Sense Evaluation, 08. 21. URL: https://www.commonsenseevaluation.com/2013/08/21/the-pussification-of-thewestern-male/

- Favara, Jeremiah (2016): Gods and Freaks, Soldiers and Men: Gender, Technologies and Marvel's Avengers. In Marvel Comics into Film: Essays on Adaptations Since the 1940s. Szerk. Matthew J. McEniry, Robert Moses és Robert G. Weiner. Jefferson, NC, McFarland, 177-88.

- Feulner, Edwin J. és Brian Tracey (2012): The American Spirit: Celebrating the Virtues and Values That Make Us Great. Nashville, TN, Thomas Nelson.

- Fingeroth, Danny (2004): Superman on the Couch. New York, Continuum.

- Gaine, Vincent M. (2016): Thor God of Borders: Transnationalism and celestial connections in the superhero film. In Superheroes on World Screens. Szerk. Rayna Denison and Rachel MizseiWard. Jackson, MS, University Press of Mississippi, 36-52.

- Ginn, Sherry (2017): Introduction: Black Widow's Place in Marvel's Universes and Our Own. In Black Widow from Spy to Superhero: Essays on an Avenger with a Very Specific Skill Set. Szerk. Uö. Jefferson, NC, McFarland, 1-10. 
- Hagley, Annika és Harrison, Michael (2014): The resurgent superhero genre in film gives insights into the American psyche and political identities post-September 11. LSE US Centre Blog, 01 20. URL: http://blogs.lse.ac.uk/usappblog/2014/01/20/avengers-politics/ (2019. 12. 16.)

- Han, Angie (2016): Natalie Portman Is "Done” With the Marvel Cinematic Universe. Slash Film, 08. 17. URL: https://www.slashfilm.com/natalie-portman-marvel/

- Hiddlestone, Tom (2012): Superheroes movies like Avengers Assemble should not be scorned. The Guardian, 04. 19. URL: https://www.theguardian.com/film/filmblog/2012/apr/19/avengersassemble-tom-hiddleston-superhero

- Hill, Kyle (2013): Getting the God of Thunder's Science Straight. Scientific American, 11. 08. URL: https://blogs.scientificamerican.com/but-not-simpler/getting-the-god-ofthundere28099s-science-straight/

- Jeffords, Susan (1994): Hard Bodies: Hollywood Masculinity in the Reagan Era. New Brunswick, NJ, Rutgers University Press.

- Johnson, Chalmers (2004): The Sorrows of Empire: Militarism, Secrecy, and the End of the Republic. New York, Metropolitan Books.

- Kakalios, James (2010): The Physics of Superheroes. New York, Penguin.

- Kaveney, Roz és Jennifer Stoy (szerk.) (2010): Battlestar Galactica: Investigating Flesh, Spirit, and Steel. London, IB Tauris.

https://doi.org/10.5040/9780755698059

- Kellner, Douglas (2009): Cinema Wars: Hollywood Film and Politics in the Bush-Cheney Era. Chichester, Wiley Blackwell.

- King, John (2002): Bush calls Saddam "the guy who tried to kill my dad”. CNN, 09. 27. URL: https://edition.cnn.com/2002/ALLPOLITICS/09/27/bush.war.talk/

- Labuza, Peter (2011): Thor: The God Who Fell to Earth. Labuza Movies, 05. 23. URL: http://labuzamovies.blogspot.com/2011/05/thor-god-who-fell-to-earth.html

- LaSalle, Mick (2013): Nordic downhill: Ponderous "Dark World" lacks charm of 1st "Thor". San Francisco Chronicle, 11. 07. URL: https://www.sfchronicle.com/movies/article/Nordicdownhill-Ponderous-Dark-World-lacks-4965629.php

- Lauzen, Martha M. (2016): It's a Man's (Celluloid) World: Portrayals of Female Characters in the Top 100 Films of 2015. Center for the Study of Women in Television $\&$ Film. URL: http://womenintvfilm.sdsu.edu/files/2015_Its_a_Mans_Celluloid_World_Report.pdf

- Lefler, Rachel (2015): Why a feminist takeover of Hollywood is a problem and why it's happening. A Voice for Men, 05. 27. URL: https://www.avoiceformen.com/featured/why-afeminist-takeover-of-hollywood-is-a-problem-and-why-its-happening/

- Lindow, John (2002): Mythology: A Guide to Gods, Heroes, Rituals, and Beliefs. Oxford, Oxford University Press.

- LoCicero, Don (2007): Superheroes and Gods: A Comparative Study from Babylonia to Batman. Jefferson, MC, McFarland.

- Masters, Kim (2011): “Thor 2” Star Natalie Portman Furious Over Director Patty Jenkins' Departure. The Hollywood Reporter, 12. 14. URL: Available: http://www.hollywoodreporter.com/news/thor-2-natalie-portman-marvel-patty-jenkins272978

- McAteer, John (2016): The Gospel According to Marvel. Christian Research Journal, 38: 3. Online. Available http://www.equip.org/PDF/JAF1383.pdf 
- McSweeney, Terence (2014): The 'War on Terror' and American Film: 9/11 Frames Per Second. Edinburgh, Edinburgh University Press. https://doi.org/10.3366/edinburgh/9780748693092.001.0001

- Mills, Anthony R. (2013): American Theology, Superhero Comics, and Cinema: The Marvel of Stan Lee and the Revolution of a Genre. Abingdon, Routledge. https://doi.org/10.4324/9780203754047

- Moore, Stuart and Marie Javins (2013): Marvel's Thor: The Dark World - The Art of the Movie. New York, Marvel.

- Morrison, Grant (2012): SuperGods: Our World in the Age of the Superhero. London, Random House.

- Noonan, Peggy (2001): Welcome Back, Duke: From the ashes of Sept. 11 arise the manly virtues. Wall Street Journal, 10. 12. URL: http://online.wsj.com/article/SB122451174798650085.html

- Noonan, Peggy (2003): The Right Man. The Washington Post. 01. 30. URL: Available: http://online.wsj.com/article/SB1043895876926710064.html

- Purse, Lisa (2011b): Return of the "Angry Woman": Authenticating Female Physical Action in Contemporary Cinema. In Women on Screen: Feminism and Femininity in Visual Culture. Szerk. Melanie Waters. London, Palgrave Macmillan, 185-98. https://doi.org/10.1057/9780230301979_13

- Reinhartz, Adele (2003): Jesus on the Silver Screen. In Revelation: Representations of Christ in Photography. Szerk. Nissan N. Perez. London, Merrell/The Israel Museum, Jerusalem, 186-9.

- Saunders, Ben (2012): Do Gods Wear Capes?: Spirituality, Fantasy, and Superheroes. London and New York, Bloomsbury.

- Saunders, Martin (2016): Doctor Strange: The Most Theological Marvel Movie So Far. Christian Today. 10. 26. URL: https://www.christiantoday.com/article/doctor.strange.the.most.theological.marvel.movie.so.far/98950.htm

- Scott, A. O. and Manohla Dargis (2013): Movies in the Age of Obama. The New York Times. 01. 16.

- Singer, Matt (2011): The Summer's New Hero: Thor-Ge W. Bush. The Atlantic, 05. 09. URL: https://www.ifc.com/2011/05/the-summers-new-hero-thor-ge-w

- Smith, Stacy L., Katherine Pieper and Marc Choueiti (2017): Inclusion in the Director's Chair?: Gender, Race, \& Age of Film Directors Across 1,000 Films 2007-2016. Online. Available: https://annenberg.usc.edu/sites/default/files/2017/04/06/MDSCI_Inclusion\%20_in_the_Directors_Chair.pdf

- Smith, Stacy L., Katherine Pieper, Marc Choueiti, Traci Gillig, Carmen Lee and Dylan DeLuca (2015a): Inequality in 700 Popular Films: Examining Portrayals of Gender, Race, $\&$ LGBT Status from 2007 to 2014. Online, Available:

http://annenberg.usc.edu/pages/ /media/MDSCI/Inequality\%20in\%20700\%20Popular\%20Films\%208215\%20Fin

- Smith, Stacy L. et al (2015b): Inequality in 800 Popular Films: Examining Portrayals of Gender, Race, \& LGBT Status from 2007 to 2015. Online, URL:

http://annenberg.usc.edu/pages/ /media/MDSCI/Dr\%20Stacy\%20L\%20Smith\%20Inequality\%20in\%20800\%20Fi

- Stewart, Henry (2011): Blockbuster: Bush v. Thor. The L Magazine, 06. 05. URL: http://www.thelmagazine.com/2011/05/blockbluster-bush-v-thor/

- Tasker, Yvonne (1993): Spectacular Bodies: Gender, Genre and the Action Cinema. London - New York, Routledge. 
- Toh, Justine (2010): The Tools and Toys of (the) War (on Terror): Consumer Desire, Military Fetish, and Regime Change in Batman Begins. In Reframing 9/11: Film, Popular Culture and the War on Terror. Szerk. Jeff Birkenstein, Karen Randell és Anna Froula. New York, Continuum, 127-39.

https://doi.org/10.5040/9781628928280.ch-011

- Trump, Donald J. (2016): Election night victory speech. New York, november 9.

- Trump, Donald J. (2017): Inauguration speech. Washington, január 20.

- Tyson, Neil Degrasse (2013): Twitter feed. 02. 05. URL: https://twitter.com/neiltyson/status/298856970180505600

- Walderzak, Joseph (2016): Damsels in Transgress: The Empowerment of the Damsel in the Marvel Cinematic Universe. In Marvel Comics into Film: Essays on Adaptations Since the 1940s. Szerk. Matthew J. McEniry, Robert M.Peaslee és Robert G. Weiner. Jefferson, NC, McFarland, 150-64.

- Watercutter, Angela (2016): The "Jane Test", a New Way to Tell if Your Scripts Are Sexist. Wired, 02. 12. URL: https://www.wired.com/2016/02/jane-test-movie-gender-roles/

- Weisberg, Jacob (2008): The Bush Tragedy. London, Bloomsbury.

- Wood, Robin (1998): Sexual Politics and Narrative Film, Hollywood and Beyond. New York, Columbia University Press.

\section{Filmográfia}

- 12 majom (12 Monkeys. Terry Gilliam, 1995)

- A galaxis ốrzöi 2. (Guardians of the Galaxy: Vol. 2. James Gunn, 2017)

- A galaxis ốrzối (Guardians of the Galaxy. James Gunn, 2014)

- A gyúrük ura - A gyúrü szövetsége (The Lord of the Rings: The Fellowship of the Ring. Peter Jackson, 2001)

- A gyúrük ura - A két torony (The Lord of the Rings: The Two Towers, Peter Jackson, 2002)

- A gyúrük ura - A király visszatér (The Lord of the Rings: The Return of the King. Peter Jackson, 2003)

- A Hangya (Ant-Man. Peyton Reed, 2015)

- A hihetetlen Hulk (The Incredible Hulk. Louis Leterrier, 2008)

- A jó, a rossz és a csúf (The Good, the Bad and the Ugly. Sergio Leone, 1966)

- A S.H.I.E.L.D. ügynökei (Marvel's Agents of S.H.I.E.L.D. TV-sorozat. ABC, 2013-)

- A sötét lovag: Felemelkedés (The Dark Knight Rises. Christopher Nolan, 2012)

- Amerika kapitány: Az elsố bosszúálló (Captain America: The First Avenger. Joe Johnston, 2011)

- Amerika kapitány: Polgárháború (Captain America: Civil War. Russo Brothers, 2016)

- Az éhezók viadala (Hunger Games. Gary Ross, 2012)

- Az éhezók viadala: A kiválasztott - 1. rész (Hunger Games: Mockingjay - Part 1. Francis Lawrence, 2014)

- Az éhezốk viadala: A kiválasztott - 2. rész (Hunger Games: Mockingjay - Part 2. Francis Lawrence, 2015)

- Az éhezók viadala: Futótüz (Hunger Games: Catching Fire. Francis Lawrence, 2013)

- Az Óriásöló (Jack the Giant Slayer. Bryan Singer, 2013) 
- Banks úr megmentése (Saving Mr. Banks. John Lee Hancock, 2013)

- Bosszúállók (The Avengers. Joss Whedon, 2012)

- Bosszúállók: Ultron kora (Avengers: Age of Ultron. Joss Whedon, 2015)

- Carter ügynök (Marvel's Agent Carter. TV-sorozat. ABC, 2015-16)

- Csillagok háborúja: Ébredố erô (Star Wars: The Force Awakens. J.J. Abrams, 2015)

- Délidô (High Noon. Fred Zinneman, 1952)

- Doktor Strange (Scott Derrickson, 2016)

1. T. a földönkivüli (E.T. The Extra-Terrestrial. Steven Spielberg, 1982)

- Halálos iramban 6 (The Fast and the Furious 6. Justin Lin, 2013)

- Mátrix (The Matrix. Lana Wachowski, Lilly Wachowski, 1999)

- Nagy Sándor (Alexander. Oliver Stone, 2004)

- Thor: Sötét világ (Thor: The Dark World. Alan Foster, 2014)

- Titánok haragja (Wrath of the Titans. Jonathan Liebesman, 2012)

- Vasember (Iron Man. Jon Favreau, 2008)

- Vasember 2 (Iron Man 2. Jon Favreau, 2010)

- Vasember 3 (Iron Man 3. Shane Black, 2013)

- $W$ (Oliver Stone, 2008)

- Wonder Woman (Patty Jenkins, 2017) 
(c) Apertúra, 2019. Ỗsz | www.apertura.hu

webcím: https://www.apertura.hu/2019/osz/mcsweeney-a-mennydorges-istenenek-

amerikanizalasa-hogyan-lesz-a-fiuuralkodobol-asgard-jogos-kiralya-a-thorban/

https://doi.org/10.31176/apertura.2019.15.1.4

(Q)opertúro 